\title{
Discovery of Beclabuvir: A Potent Allosteric Inhibitor of the Hepatitis C Virus Polymerase
}

\author{
Robert G. Gentles
}

\begin{abstract}
Contents

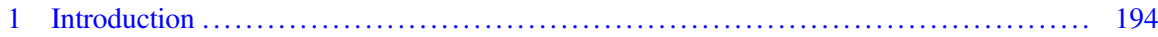

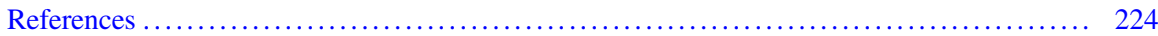

\begin{abstract}
The discovery of beclabuvir occurred through an iterative series of structure-activity relationship studies directed at the optimization of a novel class of indolobenzazepines. Within this research, a strategic decision to abandon a highly potent but physiochemically problematic series in favor of one of lower molecular weight and potency was key in the realization of the program's objectives. Subsequent cycles of analog design incorporating progressive conformational constraints successfully addressed off-target liabilities and identified compounds with improved physiochemical profiles. Ultimately, a class of alkyl-bridged piperazine carboxamides was found to be of particular interest, and from this series, beclabuvir was identified as having superior antiviral, safety, and pharmacokinetic properties. The clinical evaluation of beclabuvir in combination with both the NS5A replication complex inhibitor daclatasvir and the NS3 protease inhibitor asunaprevir in a single, fixed-dose formulation (Ximency) resulted in the approval by the Japanese Pharmaceutical and Food Safety Bureau for its use in the treatment of patients infected with genotype $1 \mathrm{HCV}$.
\end{abstract}

Keywords Asunaprevir, Beclabuvir, Daclatasvir, HCV, Hepatitis C virus, NS5B inhibitor, Polymerase inhibitor

R. G. Gentles ( $\triangle)$

Department of Discovery Chemistry and Molecular Technologies, Bristol-Myers Squibb

Research and Development, Wallingford, CT, USA

e-mail: robert.gentles@bms.com 


\section{Introduction}

As part of a large multidisciplinary team at Bristol-Myers Squibb tasked with the development of effective oral treatments for hepatitis $\mathrm{C}$ virus (HCV) infections, we were involved in the identification of drug combinations that would target two or preferably three orthogonal viral proteins [1]. This strategy was predicated on the success of co-administration of agents of distinct mechanisms of action used to treat human immunodeficiency virus-1 (HIV-1) infections; in these instances, tertiary combinations of direct-acting antivirals (DAAs) were effective in controlling the emergence of viral resistance, a necessary feature of any therapy targeting a cure in $\mathrm{HCV}$ infection [2].

The focus of our specific efforts was the discovery of potent inhibitors of the HCV NS5B polymerase enzyme [3]. As polymerases of a number of viruses had been shown to be attractive targets for the development of DAA therapeutics, we embarked on this discovery with the assurance of at least some successful precedent [4]. At the inception of our research, the optimal therapy for $\mathrm{HCV}$ patients required extended (48 weeks) co-administration of pegylated interferon- $\alpha$ (Peg-IFN) and ribavirin (RBV), a regime that resulted in only 40-50\% of genotype 1 patients achieving a sustained viral response (SVR), as defined as the absence of detectable viral RNA in serum 6 months after conclusion of treatment [5]. Additionally, Peg-IFN treatments are associated with severe flu-like side effects, as well as fatigue, drowsiness, and anemia. This leads to significant patient discontinuations despite the severe prognosis of the untreated disease [6]. The necessity to address the substantial unmet medical need with a well-tolerated and effective oral therapy was the compelling impetus for the initiation of our research.

$\mathrm{HCV}$ is a member of the Flaviviridae family of viruses and has a single-stranded, positive-sense RNA genome [7, 8]. Variability within the gene that encodes the polymerase enzyme, the nonstructural protein $5 \mathrm{~B}$ (NS5B), is used to classify the virus into seven major genotypes (1-7) and five principal subclasses (a, b, c, d, and e) [9]. The genotypes vary geographically, with genotype 1 predominating in North America, Europe, and Japan, with smaller populations in these areas also infected with genotypes 2 and 3. Genotypes 4 and 5 are found almost exclusively in Africa, whereas genotype 6 is most prevalent in Asia [10,11]. As an initial focus, and partly driven by the properties of the program's early lead compounds, targeting of genotype 1 was prioritized, with a longer-term objective being the development of pan-genotypic inhibitors.

NS5B is an RNA-dependent RNA polymerase that forms the catalytic core of the viral replicase complex [12-14]. It is essential for HCV replication, and given that no mammalian congener exists, targeting this enzyme was anticipated to have a reduced risk of unwanted side effects [15]. Additionally, priority was given to the identification of allosteric inhibitors in the belief that the developability of such compounds may be more facile than traditional active-site nucleoside-based inhibitors.

Our initial attempts at identification of viable leads through a high-throughput screening campaign proved to be frustrating; while inhibitors of the enzyme were 
identified, attempts to advance these series in the context of cellular replicon assays proved to be challenging, primarily due to difficulties in achieving cellular activity without obfuscating cytotoxicity. In this review, the biochemical enzyme assays (for which $\mathrm{IC}_{50} \mathrm{~s}$ are reported) were performed with recombinant wild-type NS5B (genotype $1 \mathrm{~b}$, Con1) containing a carboxyl-terminal deletion of 18 amino acids and a resistance variant containing a single amino acid substitution, P495L. The inhibition of the incorporation of radiolabeled nucleotides in these transcriptional assays was detected using scintillation proximity assay (SPA) beads [16]. Compound inhibitory activities were also determined in replicon systems (for which we report $\mathrm{EC}_{50} \mathrm{~s}$ ) consisting of human hepatocyte-derived cell lines (Huh-7) that constitutively express sub-genomic HCV RNA (genotypes 1b and 1a, Con1 and H77c, respectively) encoding essential cis-elements and the $\mathrm{HCV}$ nonstructural proteins required for RNA replication. Inhibition of viral RNA replication correlates with a decrease in HCV RNA and protein production. Reduction in HCV replication was measured indirectly by monitoring HCV NS3 protease activity using a fluorescence resonance energy transfer (FRET) assay [17-19]. The cytotoxicity of compounds in the replicon host cells was determined by measurement of the fluorescence of Alamar blue dye, an indicator of mitochondrial function and cellular metabolism.

Given the lack of success in identifying progressable leads from in-house sources, the program's focus shifted to the evaluation of reported inhibitors, and we initially attempted to characterize and investigate the indole and benzimidazole chemotypes 1 and 2 (Fig. 1) [20,21]. While these compounds exhibited modest antiviral activity in the genotype $1 \mathrm{~b}$ replicon assay $\left(\mathrm{EC}_{50}\right.$ values of $400 \mathrm{nM}$ and $100 \mathrm{nM}$, respectively), both displayed good cellular therapeutic indexes $\left(\mathrm{CC}_{50} / \mathrm{EC}_{50}>20\right)$, and it was considered that opportunities existed to address what appeared to be structural and physiochemical liabilities in these series.

Considering first compound $\mathbf{1}$, of the many initiatives undertaken with this chemotype, one of the more productive involved a de-annulation derived from a one-carbon excision from the parent heterocycle [22]. This generated the imidazoleappended acrylate 3 shown in Fig. 2. Encouragingly, this derivative retained a significant activity and prompted the evaluation of a number of isosteric heterocycles. Unfortunately, in the case of 1,3,5-substituted pyrazoles, as exemplified by
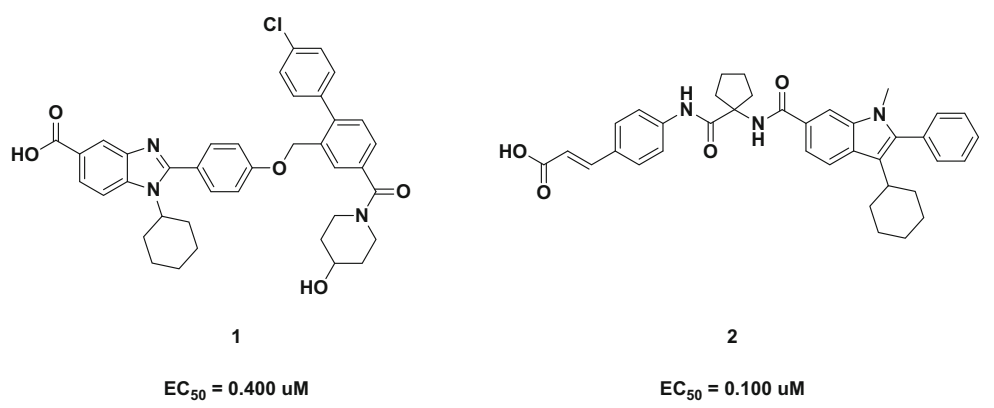

Fig. 1 Literature HCV NS5B inhibitors 


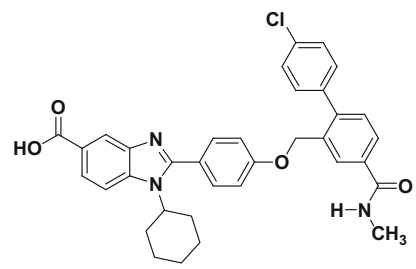

1

$\mathrm{IC}_{50}=0.64 \mu \mathrm{M}$

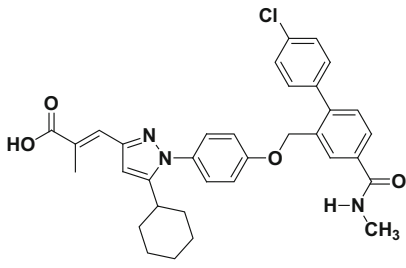

$\mathrm{IC}_{50}=4.0 \mu \mathrm{M}$

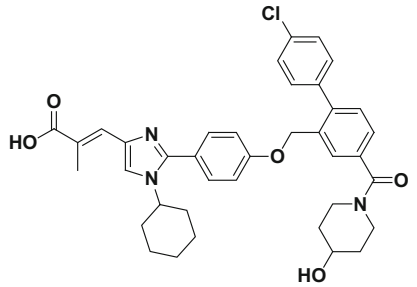

$\mathrm{IC}_{50}=1.62 \mu \mathrm{M}$

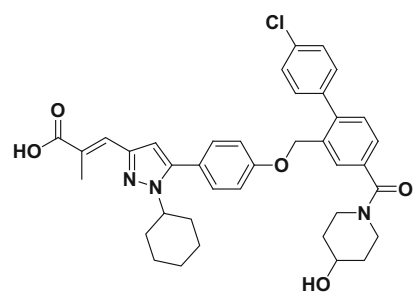

5

$\mathrm{IC}_{50}=0.38 \mu \mathrm{M}$

Fig. 2 Exploratory investigations on benzimidazole lead chemotype

compound 4, it was disappointing that these proved to be less active than the parent benzimidazole. Interestingly, however, the isomeric derivative $\mathbf{5}$ was found to be essentially equipotent with the original lead; this was attributed to a reduction in allylic strain in a putative bioactive conformation [22]. In modeling studies, the differences in potencies of many of the heterocycles explored could be most comprehensively rationalized by considering subtle variations in the vectors defined by the distances between the cyclohexyl moiety and the acid functionalities of the various analogs tested. It was known that the cyclohexyl group appeared to function as an anchor, binding the ligand to NS5B; variations in the distances between this functionality and the acid moieties were projected to modulate key binding interactions between each of the ligands' carboxylate moieties and Arg503 of NS5B, and this concept could rationalize much of the potency variations observed with the analogs explored.

Given the preference for the geometry presented by compound $\mathbf{5}$, this molecular silhouette was used in subsequent studies as a template to assess a series of derivatives represented by the generic structure shown in Fig. 3.

Using this scaffold efforts were directed at the introduction of structural diversity at the $\mathrm{R}_{1}, \mathrm{R}_{2}$, and $\mathrm{Ar}_{3}$ vectors, and the attendant analog screen resulted in the identification of the piperidine carboxamide $\mathbf{6}$, a compound that exhibited moderately potent inhibition in both the NS5B enzyme assay and in a genotype $1 \mathrm{~b}$ replicon system, as shown in Fig. 4. The compound was determined to be relatively nontoxic $\left(\mathrm{CC}_{50}=25 \mu \mathrm{M}\right)$ and had a therapeutic index of $>60$. Furthermore, the closely 


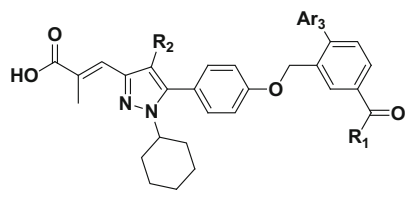

Fig. 3 Molecular template utilized in pyrazole SAR studies
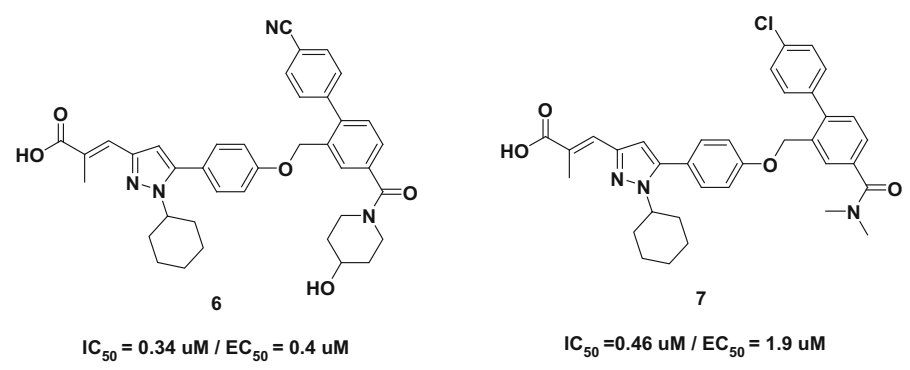

Fig. 4 Early pyrazole lead structures

related analog 7 not only exhibited similar activity but was shown to have good bioavailability in rat when dosed orally at $2 \mathrm{mg} / \mathrm{kg},\left(\mathrm{F}=69 \%, t_{1 / 2}=1.3 \pm 0.7 \mathrm{~h}\right)$.

These activities and profiles were encouraging and some clear paths for further advancement were identified. However, more compelling opportunities were presenting themselves as a result of concurrent efforts on the indole chemotype 2 (Fig. 5), and these subsequently became the focus of attention.

The initial explorations with this chemotype contrasted with the approach that was adopted above, in that an annulation strategy was first investigated [23]. In order to address what was perceived as liabilities within the series, specifically the high molecular weight, polyamidic character, and high lipophilicity, avenues were sought, whereby increased potency could be achieved in smaller, more ligandefficient derivatives.

It was projected that this might be achieved through the introduction of novel bridging tethers between the pendent phenyl moiety and the core indole heterocycle. In addition, it was anticipated that such a strategy would induce a degree of pre-organization through conformational constraint, as well as provide a scaffold from which additional functionality could be extended along unique vectors. In some variants of this basic concept, additional polarity was introduced into the system through the incorporation of heteroatoms and polar linking moieties within the bridging groups themselves. To explore these concepts, the simple 6-carboxylate derivatives were examined first as these would lead to lower molecular weight, non-amidic analogs. However, to fully assess the potential of the bridging elements, the related cinnamic acid conjugates were also considered. This led to the synthesis of the indolo-fused heterocycles shown in Fig. 6. 


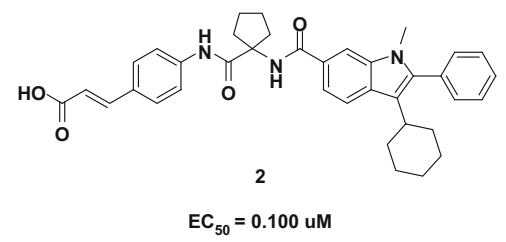

Fig. 5 Initial indole lead structure

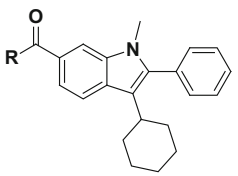

8: $R=R_{1} E C_{50}=2.8 \mu M$ 9: $R=R_{2} E_{50}=0.10 \mu \mathrm{M}$

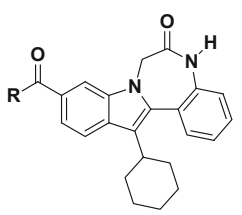

14: $R=R_{1} E C_{50}=0.24 \mu M$ 15: $R=R_{2} E_{50}=0.01 \mu M$

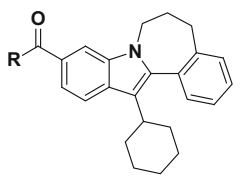

10: $R=R_{1} E_{50}=0.7 \mu M$ 11: $R=R_{2} E_{50}=0.02 \mu \mathrm{M}$
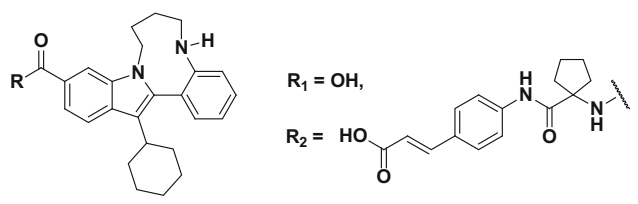

16: $R=R_{1} E C_{50}=0.27 \mu \mathrm{M}$ 17: $R=R_{2} E_{50}=0.02 \mu \mathrm{M}$

Fig. 6 Truncated and extended indolo-fused heterocyclic NS5B inhibitors

The low-energy geometries of the truncated indolo acids were explored using molecular mechanics employing an OPLS force field [24]. Optimized structures are shown in Fig. 7, and the dihedral angles between the phenyl and indole rings for each heterocycle are listed in Table 1. In the interpretation of the subsequently derived structure-activity relationships (SARs), compounds $\mathbf{8}$ and $\mathbf{9}$ were used as primary comparators.

What emerged quickly from these investigations was that all of the annulations were associated with significant (four- to tenfold) improvements in potency, in both the truncated and the extended cinnamic acid series. The optimized dihedral angles between the pendent phenyl and the indole cores did not appear to be key determinants of activity since equipotent derivatives with inclinations between these moieties of between $43^{\circ}$ and $70^{\circ}$ were observed. This suggested that the preferred bioactive conformations could be easily accessed in all of the ring systems explored. None of the indolo-fused heterocyles are rigid, and, correspondingly, any entropic factors positively contributing to binding may be quite modest. This, in conjunction with the observation that the introduction of polarity into various positions on the bridging elements was not only tolerated, but could be associated with further improvements in activity, as seen in analogs 12 through 16, was supportive of the 


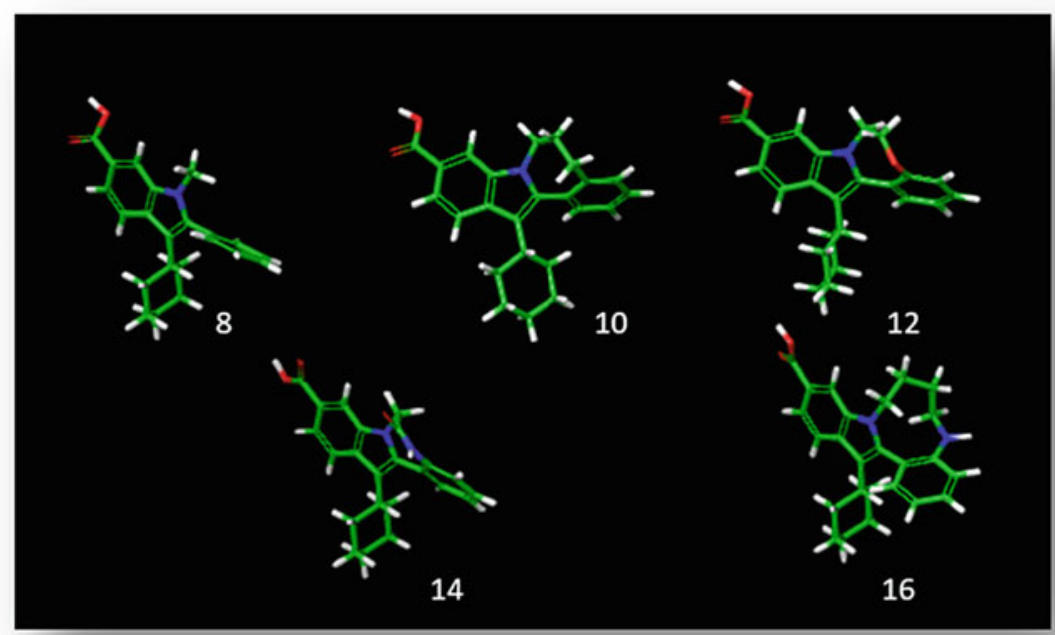

Fig. 7 Molecular mechanics (OPLS) minimized structures of the indolo-fused heterocycles [24]

Table 1 Dihedral angles of bridged indolo analogs and their related replicon activities

\begin{tabular}{l|l|l}
\hline Compound & Dihedral angle & Replicon $1 \mathrm{~B} \mathrm{EC}_{50}(\mu \mathrm{M})^{\mathrm{a}}$ \\
\hline $\mathbf{8}$ & $66^{\circ}$ & 2.8 \\
\hline $\mathbf{1 0}$ & $45^{\circ}$ & 0.6 \\
\hline $\mathbf{1 2}$ & $49^{\circ}$ & 0.7 \\
\hline $\mathbf{1 4}$ & $43^{\circ}$ & 0.2 \\
\hline $\mathbf{1 6}$ & $71^{\circ}$ & 0.3 \\
\hline
\end{tabular}

${ }^{a}$ Values are means of three experiments. All analogs were equipotent with respect to replicon genotype $1 \mathrm{a}$ and $1 \mathrm{~b}$ inhibition

interpretation of productive interactions between the tethering elements and the protein. Furthermore, the significant enhancement of activity noted in compounds $\mathbf{1 4}$ and $\mathbf{1 5}$ gave an early insight into the possibility of further incorporation of amidic motifs at this position on the chemotype, vide infra.

Within the extended cinnamate series, compound 15 was of particular note given its exquisite potency, displaying $\mathrm{EC}_{50}$ values of $10 \mathrm{nM}$ and $8 \mathrm{nM}$ against genotypes $1 \mathrm{a}$ and $1 \mathrm{~b}$, respectively. This represented a milestone within the program since it achieved the clinical candidate potency objectives of $<10 \mathrm{nM}$ against both of the primary targeted viral genotypes. A co-crystal structure of this analog complexed to NS5B [1b Bartenschlager construct] was obtained and is shown in Fig. 8 [25, 26].

It can be seen in the depiction above that NS5B adopts the figurative right-hand topology typically observed with RNA polymerases. The cinnamate moiety is observed to bind in the thumb domain of the enzyme with the cyclohexyl ring 


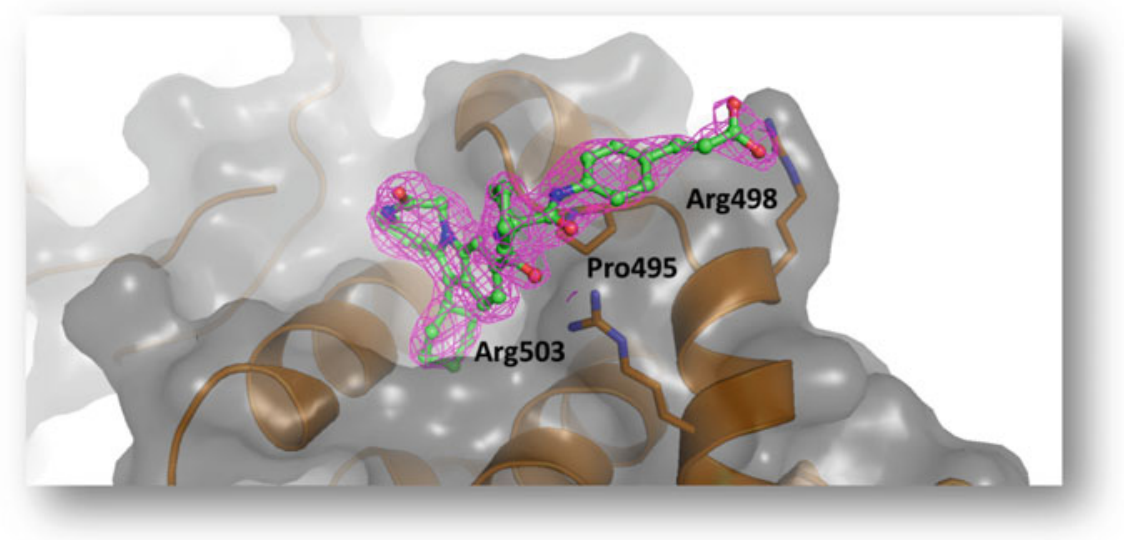

Fig. 8 Compound 8 bound to HCV genotype1b NS5B (Bartenschlager) [25]. The protein proximal to the P495 site is represented by a surface (gray) and cartoon (orange). The side chains of Pro495, $\operatorname{Arg} 498$, and Arg503 are represented with sticks (orange carbon atoms), and compound $\mathbf{8}$ is depicted in ball-and-stick representation with green carbon atoms. The initial (prior to placing compound $\mathbf{8}$ in the model) $2 \mathrm{Fo}-\mathrm{Fc}$ electron density is contoured at $1 \sigma$ (magenta). Image created with PyMol (www. pymol.org)

occupying a small hydrophobic pocket proximal to P495 (explaining the $\mathrm{P} 495 \mathrm{~L}$ resistance profile of all of the compounds of the current discussion, vide infra) $[23,26]$. The amidic N-H moiety of the proximal carboxamide forms a hydrogen bond with ARG 503, and the terminal carboxylate forms a salt bridge with R498. The fused, formerly pendent phenyl group lies in a hydrophobic cleft on the surface of NS5B and is inclined at an angle of $\sim 46^{\circ}$ relative to the indole ring. This is similar to that observed in the minimized structure of the indolobenzazepinones 14 and $\mathbf{1 5}$ and in these specific analogs doubtless contributes to their potency. It should be noted that in the above structure and in others that were obtained, the $\Delta 1$ finger domain of the enzyme could not be resolved due to disorder in this region of the peptide. This significantly curtailed the ability to fully adopt a rational design approach, especially in relation to modifications of the bridging tethers, and this will be elaborated on later in this account.

A number of potent leads from these efforts were advanced into a succession of rat pharmacokinetic (PK) studies, selected results from which are shown in Table 2. A striking aspect of these data was the relatively poor PK profiles exhibited by the cinnamate derivatives 11, 15, and 17. All showed low bioavailability and all exhibited moderate to high clearances. This could be rationalized by recognizing that these analogs retained both the polyamidic and acidic character of the original lead. Much more interesting, however, was that the acidic polar lactam 14 exhibited significantly improved exposure despite displaying high clearance. It was quickly established that the latter was due to glucuronidation of the carboxylate moiety, an 
Table 2 Rat PK results observed with select examples of the indolo-fused tetracyclic NS5B inhibitors shown in Fig. 2

\begin{tabular}{l|l|l|c}
\hline Compound & $\mathrm{F}(\%)^{\mathrm{a}}$ & AUC $(\mu \mathrm{M} \mathrm{h})$ & Clearance $(\mathrm{mL} / \mathrm{min} / \mathrm{kg})^{\mathrm{b}}$ \\
\hline $\mathbf{1 0}$ & 6 & 1.3 & 53 \\
\hline $\mathbf{1 1}$ & 8 & 0.3 & 250 \\
\hline $\mathbf{1 3}$ & 5 & 0.8 & 17 \\
\hline $\mathbf{1 4}$ & 18 & 2.2 & 35 \\
\hline $\mathbf{1 5}$ & 3 & 0.7 & 13 \\
\hline $\mathbf{1 7}$ & 12 & 3.6 & 9 \\
\hline
\end{tabular}

${ }^{\mathrm{a}}$ Oral bioavailability

${ }^{\mathrm{b}} \mathrm{IV}$ (dose $2 \mathrm{mg} / \mathrm{kg}$ )

issue that might be resolved given the structural information obtained from the data shown in Fig. 8, as well as that from related structures.

This proved to be a critical and pivotal point in the identification of beclabuvir: the decision was made to pursue the optimization of the truncated indolobenzodiazepine 14 rather than persist with the more potent, extended variants typified by $\mathbf{1 5}$. This change in the focus of the program was driven by the realization that there was no clear path to address the issues identified with the latter compound, whereas the problems associated with the truncated version seemed more tractable, assuming that the potency of this series could be advanced sufficiently.

From this point, two interdependent avenues of research were conducted. The first attempted to establish if potency could be enhanced by further modification of the bridging element, and the second was to address the glucuronidation issue which, if resolved successfully, would result in significantly improved PK properties.

An extensive array of fused heterocycles were explored in the context of modifications of the bridging motifs, but one of the most significant resulted from a transposition of the amide from the lactam topology in 14, to the pendent carboxamide motif, as represented by $\mathbf{1 8}$ in Fig. 9. This configuration retained the $6,5,7,6$ ring system of the parent heterocycle, and when the transposition was coupled with concomitant introduction of unsaturation into the azepine ring, the overall topology of the precursor system was recapitulated and the introduction of a chiral center obviated. Carboxamides are ubiquitous in medicinal chemistry since they can improve the solubility of a molecule as well as provide a flexible coupling element that projects both H-bonding donor and acceptor motifs for interaction with cognate targets. The incorporation of this element in an exocyclic fashion on the indolobenzazepine ring system facilitated a rapid scan of an extensive array of amines and quickly identified what proved to be a progressable series.

While a large number of carboxamides of the general structure depicted by $\mathbf{1 8}$ were found that retained significant activity, it was discovered that simple morpholine carboxamides such as 19 were among the most ligand-efficient derivatives identified, and had the best overall balance of potency and targeted genotype coverage, as can be seen from Fig. 10. 


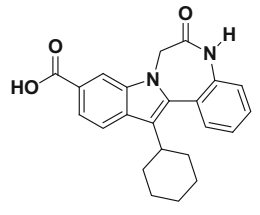

14: $\mathrm{EC}_{50}=0.24 \mathrm{uM}$

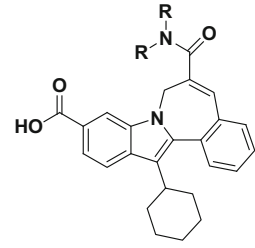

18

Fig. 9 Indole leads exhibiting transposition of carboxamide moieties

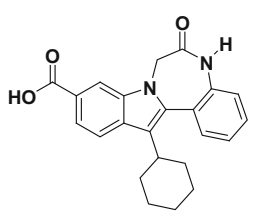

14: $\mathrm{EC}_{50} \mathrm{GT} 1 \mathrm{a}=0.170 \mu \mathrm{M}$ $\mathrm{EC}_{50}$ GT $1 \mathrm{~b}=0.240 \mu \mathrm{M}$

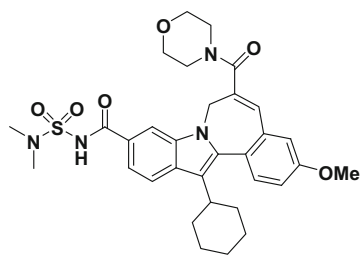

21: $\mathrm{EC}_{50} \mathrm{GT} 1 \mathrm{a}=0.060 \mu \mathrm{M}$ $\mathrm{EC}_{50}$ GT $1 \mathrm{~b}=0.060 \mu \mathrm{M}$

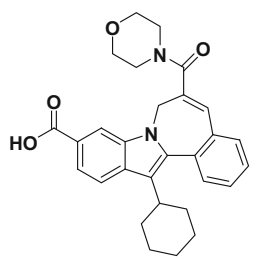

19: $\mathrm{EC}_{50} \mathrm{GT} 1 \mathrm{a}=0.400 \mu \mathrm{M}$ $\mathrm{EC}_{50}$ GT $1 \mathrm{~b}=0.360 \mu \mathrm{M}$

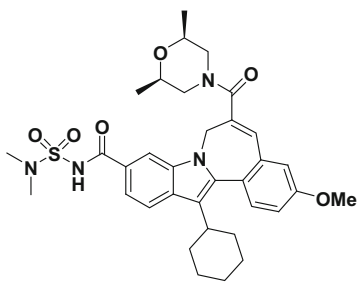

22: $\mathrm{EC}_{50} \mathrm{GT} \mathrm{1a}=0.040 \mu \mathrm{M}$

Fig. 10 Pendent morpholine and functionalized-morpholine carboxamides in lead indolobenzazepine series

However, the exposure profiles of these simple indole carboxylates following oral dosing to rats were frequently poor, as noted above. Correspondingly, a concurrent parallel effort was directed at the evaluation of acid isosteres, and a particularly productive discovery was the identification of the $N, N$-dimethylsulfamide moiety, as exhibited in analogs 20, 21, and 22 [27]. ${ }^{1}$ This modification not only modestly enhanced the activity of the series but was also found to obviate the glucuronidation issue noted previously. With the acylsulfamide 20, potencies approaching $100 \mathrm{nM}$ were achieved against the primary genotypes of interest with an analog with a significantly improved PK profile: Compound $\mathbf{2 0}$ was $30 \%$ orally bioavailable in

\footnotetext{
${ }^{1}$ The research discussed in [27] was essentially mirrored in the earlier related studies cited in the text.
} 
the rat at a dose of $5 \mathrm{mpk}$, and achieved liver levels of $24 \mu \mathrm{M}$, as determined $4 \mathrm{~h}$ post dose in an abbreviated PK study.

Further optimization of the chemotype was directed at identifying optimal substituents on the fused aryl moiety. The introduction of additional functionality at this position on the chemotype was challenging, given that the diversity elements had to be introduced at an early stage of the synthesis, as can be appreciated from the route depicted in Fig. 11.

Initial syntheses employed in these efforts introduced the aryl diversity element through boronate styrene derivatives of the type shown above. These were employed in a Suzuki coupling with the bromoindole $\mathbf{2 3}$ to give the 2-arylindoles $\mathbf{2 4}$ [2831]. Subsequent Michael addition with methyl 2-(bromomethyl)acrylate afforded dienes of the type $\mathbf{2 5}$, which were employed in an olefin metathesis ring closure to generate the intermediate indolobenzazepines 26. Subsequent derivatization of the two acid moieties allowed access to the final targets [32-34]. The yields of these reactions were frequently poor, prompting the development of the alterative synthesis depicted at the bottom of Fig. 11. This latter route utilized the arylaldehydes 27 in a tandem Michael addition/Wadsworth-Horner-Emmons reaction with tert-butyl 2-(dimethoxyphosphoryl)acrylate to generate the differentially functionalized diester intermediates 28 [35]. The two carboxylate moieties could chemoselectively be cleaved under orthogonal conditions to provide either mixed acid ester. This additional degree of freedom in the order of subsequent derivatizations expedited ensuing SAR studies.

Using these methodologies, a significant number of analogs were prepared from which it was determined that the simple 4-methoxy-appended aryl was a preferred motif. This group significantly improved the potency of analogs into which it had been incorporated, as can be seen in compound 21, the first analog in a non-cinnamate series that achieved potency of $<100 \mathrm{nM}$ in the replicon assays.

Extensive profiling of members of this series highlighted some recurrent issues, as typified by the poor solubility and human pregnane $\mathrm{X}$ receptor (hPXR) activation

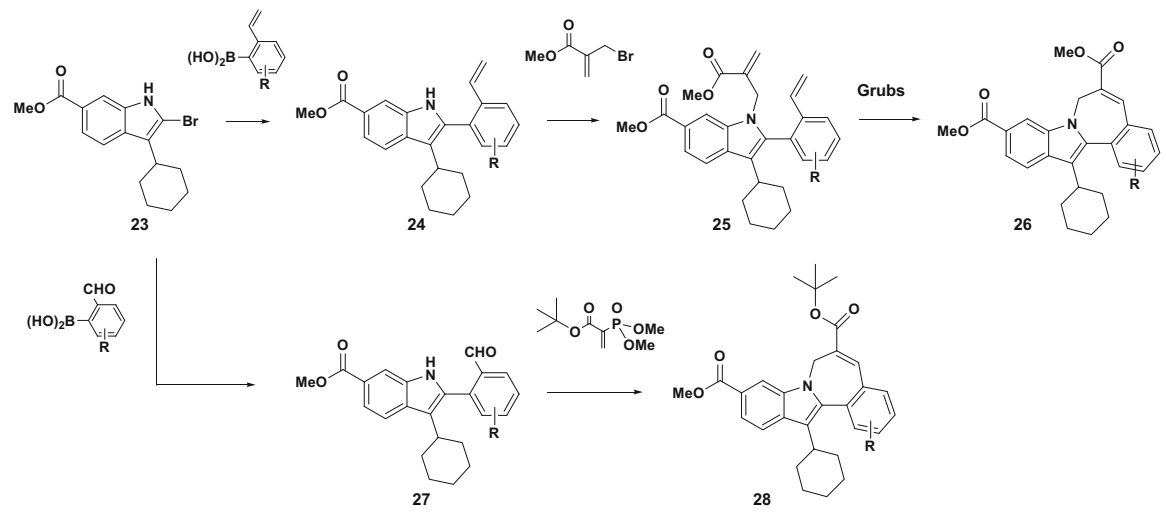

Fig. 11 Synthetic routes to access key intermediates required in the syntheses of indolobenzazepines 
exhibited by compound 20. This derivative had an amorphous aqueous solubility of $<1 \mu \mathrm{g} / \mathrm{mL}$ and an $\mathrm{IC}_{50}$ of $440 \mathrm{nM}$ in the PXR assay, indicating a significant potential for induction of drug-drug interactions (DDIs) [36]. This was of concern given the anticipated use of this inhibitor as part of a multi-DAA regime. However, continued profiling of analogs in this series demonstrated that the introduction of steric bulk around the ether element of the morpholine ring could eliminate this property, and with the simple 2,6-dimethylmorpholine derivative 22, a benchmark compound was identified that exhibited a potent and balanced genotype inhibition profile $\left(\mathrm{EC}_{501 \mathrm{a} / 1 \mathrm{~b}}=40 / 40 \mathrm{nM}\right)$ and a PXR IC 50 value of $>10 \mu \mathrm{M}$. In rat PK studies, this compound also exhibited high liver levels of $33 \mu \mathrm{M}$ when measured $4 \mathrm{~h}$ after an oral dose of $10 \mathrm{mg} / \mathrm{kg}$.

Strongly encouraged by what had been achieved, further modifications to the bridging tethers were aggressively investigated. A particularly fruitful finding in this area involved a cyclopropanation of the olefin group in the fused benzazepine moiety of the parent heterocycle. The intentions with this manipulation were twofold: firstly, to establish a supplementary degree of conformational constraint across the ring system and, secondly, to investigate possible interactions between the polarized C-Hs of the cyclopropyl motif and the NS5B protein, this interaction being of interest from prior structural investigations [23]. Furthermore, this modification had the added advantage of removing a potential Michael acceptor (although in biotransformation studies on the parent heterocycles, this reactivity was never observed).

Racemic and enantiomerically pure forms of the cyclopropylindolobenzazepines were accessed by a number of routes. However, the chemistry depicted in Fig. 12 allowed the introduction of the amine component of the carboxamide moiety at the last step of the synthesis, thus facilitating both the rapid scanning of a variety of derivatives and efficient access to enantiomerically pure analogs.

This methodology required the hydrolysis of $\mathbf{2 3}$ under basic conditions followed by coupling of the resultant acid 29 with $N, N$-dimethylsulfonylurea to provide the acyl sulfamide $\mathbf{3 0}$ [31]. This could subsequently be coupled with 4-methoxyphenylboronic acid (31) using Suzuki-Miyaura conditions to produce the aromatic aldehyde 32 [28-30]. A tandem Michael addition and Horner-WadsworthEmmons alkylation-olefination procedure employing the dimethylphosphonate $\mathbf{3 3}$ provided access to the indolobenzazepine 34 [35]. The resultant embedded methyl acrylate could be efficiently converted to the racemic cyclopropyl derivative $\mathbf{3 5}$ under Corey-Chaykovsky conditions, and subsequent chiral resolution of the racemic 35 (achievable on a multi-gram scale) using preparative chiral HPLC provided the (-)enantiomer 37 [37]. This intermediate was used to generate the more highly active enantiomers via hydrolysis to the enantiomerically pure acid $\mathbf{3 8}$ and subsequent conversion to the desired optically pure carboxamides, shown generically as $\mathbf{3 9}$. The alternate (+)-enantiomer $\mathbf{3 6}$ could be utilized in the generation of the antipodes, and these consistently exhibited a three- to fivefold loss of inhibitory activity relative to their related enantiomers. The assignment of the absolute stereochemistry in the cyclopropyl-fused analogs was determined based on data obtained from an X-ray co-crystal structure of compound $\mathbf{6 6}$ (vide infra) bound to NS5B, data that also 
<smiles>COC(=O)c1ccc2c(C3CCCCC3)c(Br)[nH]c2c1</smiles>

23

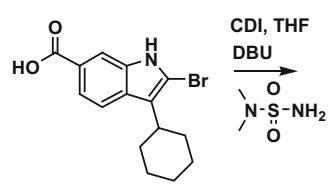

$29(99 \%)$

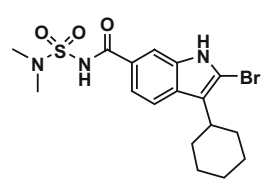

$30(74 \%)$<smiles>CCc1c(C=O)cc([18OH])cc1OC</smiles><smiles>COc1ccc(-c2[nH]c3cc(C(=O)NS(=O)(=O)N(C)C)ccc3c2C2CCCCC2)c(C)c1</smiles><smiles>C=C(C(=O)OC)P(=O)(OC)OC</smiles>

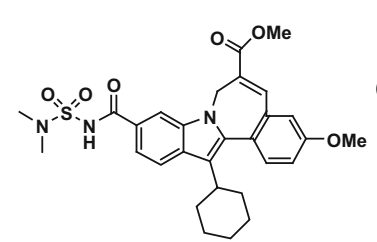

$34(71 \%)$

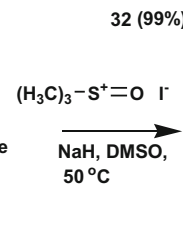

$32(99 \%)$

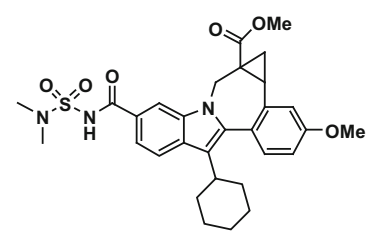

$35(83 \%)$

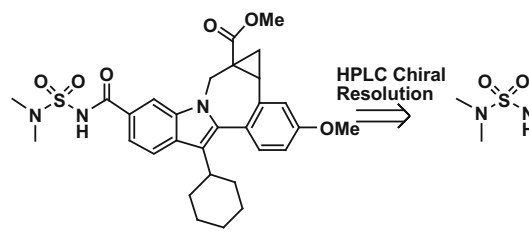

35

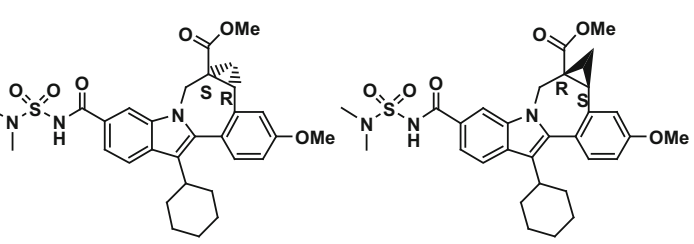

36

37

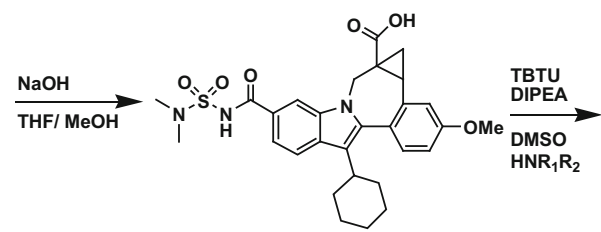

$38(60 \%)$

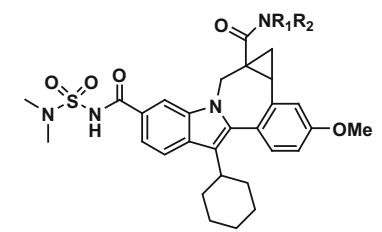

39

Fig. 12 Methodology utilized in accessing specific enantiomers of cyclopropyl fused indolobenzazepines

supported the idea of productive interactions between the hydrogen atoms of the cyclopropyl motif and NS5B.

As there was a significant motivation to quickly develop SAR within this chemotype, racemic materials were screened initially, and for those analogs that showed promise, a comprehensive assessment of the individual enantiomers was subsequently conducted. The data on selected key examples from this endeavor are shown in Fig. 13. 


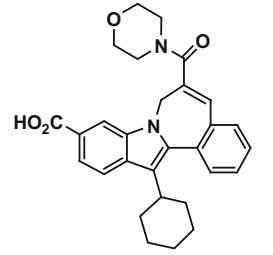

19

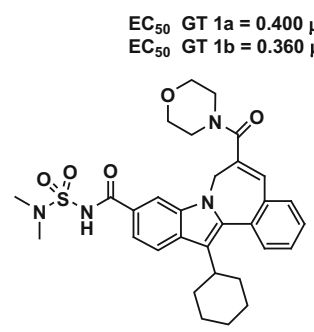

20

$E_{50}$ GT 1a $=0.120 \mu \mathrm{M}$ $\mathrm{EC}_{50} \mathrm{GT} 1 \mathrm{~b}=0.150 \mu \mathrm{M}$

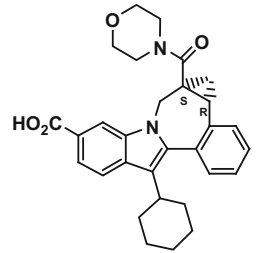

40

EC $_{50}$ GT 1a $=0.470 \mu \mathrm{M}$ $\mathrm{EC}_{50}$ GT $1 \mathrm{~b}=0.340 \mu \mathrm{M}$

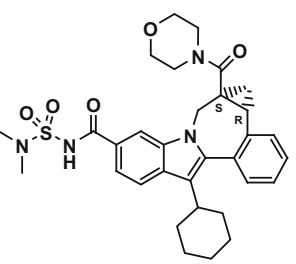

42

$E_{50}$ GT 1a $=0.260 \mu \mathrm{M}$
EC $_{50}$ GT 1b $=0.140 \mu \mathrm{M}$

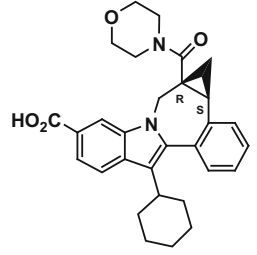

41

EC $_{50}$ GT $1 \mathrm{a}=0.040 \mu \mathrm{M}$

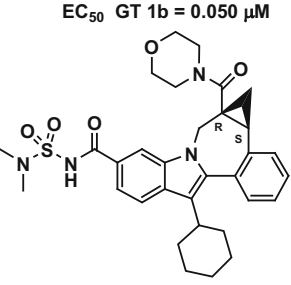

43

$\mathrm{EC}_{50} \mathrm{GT} 1 \mathrm{a}=0.030 \mu \mathrm{M}$ $\mathrm{EC}_{50} \mathrm{GT} 1 \mathrm{a}=0.030 \mu \mathrm{M}$
$\mathrm{EC}_{50} \mathrm{GT} 1 \mathrm{~b}=0.030 \mu \mathrm{M}$

Fig. 13 Impact on potency associated with the introduction of a fused cyclopropyl moiety

In reviewing these data, what became immediately apparent was that for those enantiomers with the $R$ configuration at the carboxamide-appended carbons, as in $\mathbf{4 1}$ and 43, an approximately five- to tenfold enhancement of antiviral activity was observed relative to the unsaturated congeners 19 and 20. Contrastingly, the cyclopropyl antipodes $\mathbf{4 0}$ and $\mathbf{4 2}$ were essentially equipotent with the related indolobenzazepines. Importantly, these observations confirmed a working hypothesis that the introduction of the cyclopropane modification with the correct stereochemistry might be associated with some enhancement in activity. This was predicated on modeling studies in which potential binding modes of $\mathbf{4 2}$ and $\mathbf{4 3}$ in Site I of the thumb domain of NS5B were compared, as shown in Fig. 14 [38]. In these models, both enantiomers are presented in what is calculated to be optimized conformations, and both compounds exhibit a number of redundant interactions with the enzyme. However, relative to $\mathbf{4 2}$, the antipode 43 participates in additional productive contacts, most notably between elements in the morpholine moiety and the side-chain methyl group of residue T399, as well as interaction between the polarized methylene hydrogen atoms in the cyclopropyl group and the backbone carbonyl oxygen of L492. Furthermore, the carbonyl oxygen of the acylsulfamide in 43 is better positioned for optimal H-bonding with R503. This is in contrast to what is predicted with $\mathbf{4 2}$, where steric impediments between the morpholine ring and the acylsulfamide reduce the latter's engagement with R503. Additionally, the disposition of the cyclopropyl moiety in $\mathbf{4 2}$ prevented contact of its methylene hydrogens with the carbonyl oxygen of L492. Although not apparent from these static models, it was considered reasonable to assume that the cyclopropyl moiety introduced a degree of conformational constraint within the indolobenzazepine ring system and 


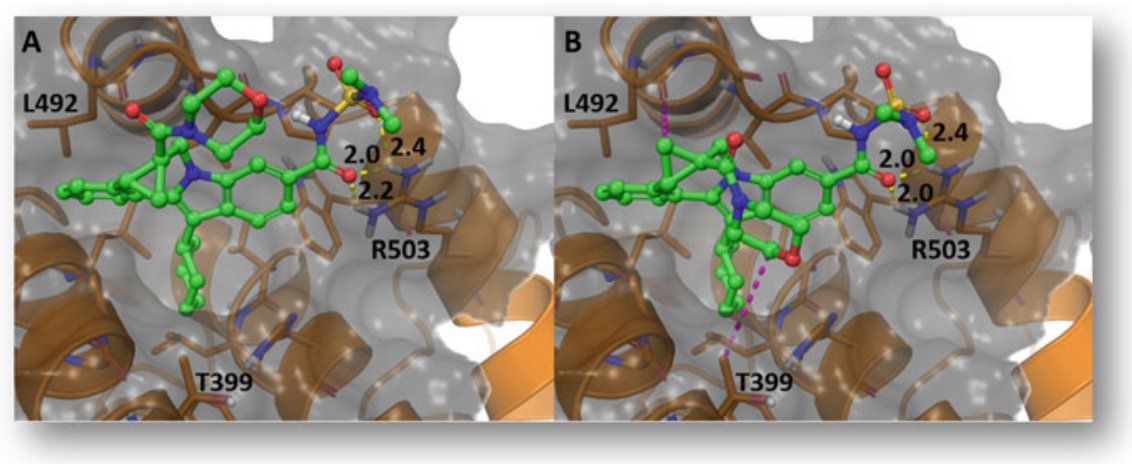

Fig. 14 Models of enantiomers 42 (a) and 43 (b) bound to the NS5B thumb site [38]. Close contacts and hydrogen bonds are depicted with magenta and yellow dashed lines, respectively, and distances are in angstroms. Images created with PyMOL (The PyMOL Molecular Graphics System, Version 2.0 Schrödinger, LLC)

that this might also contribute to the stabilization of the bound conformation shown in Fig. 14b.

As in prior studies, substitutions on the fused aryl ring were investigated and consistent with those experiences, and the 4-methoxy group was again identified as a preferred aryl substituent. Exemplified by the racemic cyclopropyl-fused analogs 44 and 45 shown in Table 3, there was a trend toward increased activity with the 4-methoxy derivatives, and the activity differential was more pronounced in the presence of $40 \%$ human serum. This effect was attributed to protein binding, and the modest right shift shown for $\mathbf{4 5}$ was observed with many members of this chemotype. However, with other closely related compounds, minor structural modifications were observed to result in pronounced loss of potency in the presence of serum.

With a high degree of confidence that the southern hemisphere of the molecule had been reasonably optimized, a rigorous effort to identify the most preferred carboxamide derivatives was initiated. As noted above, this was largely an empirical exercise; the finger domains of NS5B that might reasonably be expected to interact with the carboxamide groups were unresolved in the co-crystal structures that had been obtained. This was attributed to a high degree of mobility in this region of the protein, a proposition that was consistent with extant SAR observations that a diversity of carboxamides could be accommodated at this vector.

Notwithstanding, after comprehensive scanning exercises had been completed, a preferred topology gradually emerged, first represented by the previously discussed morpholine derivative 45. Subsequent optimization studies were directed at modulation of the properties of the series that would impact on its ability to be developed, and these initially took the form of preparing a range of closely related analogs, representative examples of which are listed in Table 4. 
Table 3 SARs associated with methoxy-substituted cyclopropylindolobenzazepines

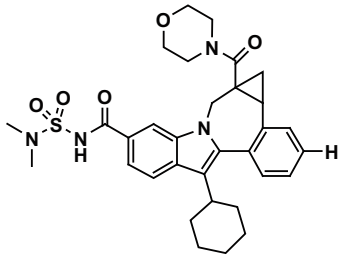

44

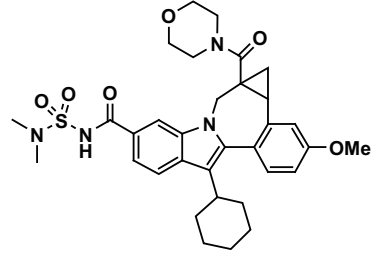

45

\begin{tabular}{|c|c|c|c|c|c|}
\hline Compound & $\begin{array}{l}1 \mathrm{~b}(\text { FRET }) \\
\mathrm{EC}_{50}(\mu \mathrm{M})\end{array}$ & $\begin{array}{l}\text { 1a (FRET) } \\
\mathrm{EC}_{50}(\mu \mathrm{M})\end{array}$ & $\begin{array}{l}1 \mathrm{~b}(\mathrm{FRET})+40 \% \\
\text { human serum } \mathrm{EC}_{50} \\
(\mu \mathrm{M})\end{array}$ & $\begin{array}{l}\mathrm{P} 495 \mathrm{~A} \\
\text { resistance } \\
\mathrm{EC}_{50}(\mu \mathrm{M})\end{array}$ & $\begin{array}{l}\text { Toxicity } \\
\mathrm{CC}_{50} \\
(\mu \mathrm{M})\end{array}$ \\
\hline 44 & 0.082 & $* 0.044$ & 0.821 & $* 0.165$ & $>10$ \\
\hline 45 & 0.061 & $* 0.054$ & 0.300 & $* 0.385$ & $>10$ \\
\hline
\end{tabular}

* $\mathrm{EC}_{50}$ values marked with an asterisk are derived from a single experiment run in duplicate; other values represent the mean of $>2$ test occasions

Table 4 SARs associated with indolobenzazepine morpholine carboxamides

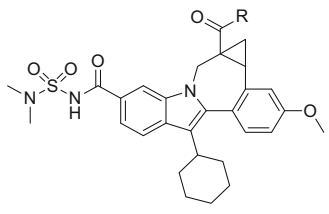

\begin{tabular}{|c|c|c|c|c|c|c|}
\hline Compound & $\mathrm{R}$ & $\begin{array}{l}1 \mathrm{~b} \\
(\mathrm{FRET}) \\
\mathrm{EC}_{50} \\
(\mu \mathrm{M}) \\
\end{array}$ & $\begin{array}{l}1 \mathrm{a} \\
(\mathrm{FRET}) \\
\mathrm{EC}_{50} \\
(\mu \mathrm{M}) \\
\end{array}$ & $\begin{array}{l}1 \mathrm{~b} \\
(\mathrm{FRET})+40 \% \\
\text { serum } \mathrm{EC}_{50}(\mu \mathrm{M})\end{array}$ & $\begin{array}{l}\text { Toxicity } \\
\mathrm{CC}_{50} \\
(\mu \mathrm{M})\end{array}$ & $\begin{array}{l}\text { PXR-TA } \\
\mathrm{EC}_{50}(\mu \mathrm{M}) / \\
Y_{\max }\end{array}$ \\
\hline 45 & & 0.061 & $* 0.054$ & 0.300 & $>10$ & ND \\
\hline 46 & & 0.012 & $* 0.006$ & 0.036 & $>10$ & $>50 / 12$ \\
\hline 47 & & 0.024 & $* 0.012$ & 0.098 & $* 9$ & ${ }^{\#} 2.8$ \\
\hline 48 & & 0.031 & $* 0.007$ & 0.114 & $>10$ & $0.6 / 144$ \\
\hline
\end{tabular}

* $\mathrm{EC}_{50}$ values marked with an asterisk are derived from a single experiment run in duplicate; other values represent the mean of $>2$ test occasions. $N D$ not determined. Homochiral designates the associated data originated from a single enantiomer; ${ }^{\#}$ Indicates an $\mathrm{EC}_{20}$ value 
Of immediate note in these data was the significant enhancement of activity seen with the more highly substituted morpholine variants, as highlighted by compound 46. This analog approached single-digit nanomolar inhibitory activity in the genotype $1 \mathrm{~b}$ and $1 \mathrm{a}$ replicons and exhibited only a modest threefold reduction of potency in the presence of $40 \%$ human serum. However, enthusiasm for this finding was tempered by the observation that a number of related analogs, including 47 and 48 , exhibited a significant activity in the hPXR transactivation assay [36]. This observation occurred with sufficient frequency within the series that efforts were directed toward identifying analogs that obviated this liability.

Few published SARs related to hPXR transactivation existed at the time of this work, and those that did were consistent with the characterization of the ligandbinding domain as large, mobile, and hydrophobic [39-42]. However, from these and related studies, it could be deduced that common structural features of hPXR ligands are that they possess an H-bond acceptor proximal to their core that is flanked by mostly hydrophobic moieties. As these elements are present within the analogs presented in Table 4, some directions for the further development of the series were suggested.

To resolve this issue, replacements for the morpholine moiety that would exploit more polar bioisosteres were sought. An initial effort in this area examined the use of 3-hydroxyazetidine as a morpholine surrogate. In this design, the distal Lewis base of the morpholine heterocycle was replaced by a polar H-bond donor. To temper what was considered to be a significant structural modification, substituents at the C3 position of the azetidine were introduced to function as shielding elements and also to array the hydrophobic moieties in a differentiated pattern. Select examples from this approach are shown in Table 5.

These changes proved to be highly effective at either eliminating or significantly ameliorating the hPXR liability. Less encouraging, however, was the inability to advance antiviral potency within the series. While the less sterically demanding derivatives such as $\mathbf{5 0}$ and $\mathbf{5 1}$ largely retained the activity, the introduction of larger aromatic moieties at the 3-position of the azetidine not only eroded antiviral potency but tended to exhibit greater cytotoxicity, as evidenced with $\mathbf{5 4}$ and $\mathbf{5 5}$.

In additional profiling studies directed at determining solubility and permeability properties (Table 6), it was determined that the majority of these compounds could be categorized as Class II within the Biopharmaceutics Classification System (BCS), that is, analogs displaying high permeability $(\mathrm{Pc}>100 \mathrm{~nm} / \mathrm{s})$ and low solubility [45].

In attempts to relate the data shown in Table 6 with in vivo observations, compounds 49 and 50 were advanced into abbreviated rat PK screens in which exposures were determined $4 \mathrm{~h}$ post-dosing. Results from these experiments are shown in Table 7. Following intravenous (IV) administration, compound 49 exhibited a high plasma clearance of $96 \mathrm{~mL} / \mathrm{min} / \mathrm{kg}$. This was attributed to extensive extraction by the liver, a conjecture consistent with the observed high L/P ratio of $>200$ (observed at the $4 \mathrm{~h}$ time point). When dosed orally (PO), 49 displayed a low plasma AUC of $41 \mathrm{nM} \mathrm{h}$, with liver concentrations of $8.8 \mu \mathrm{M}$, indicating limited absorption and possibly high hepatic extraction. In contrast, the simple 3-methylazetidine $\mathbf{5 0}$ exhibited a significantly higher plasma AUC of 9,800 nM h, 
Table 5 Structure-activity relationships and liability profiling associated with indolobenzazepine azetidine carboxamide derivatives

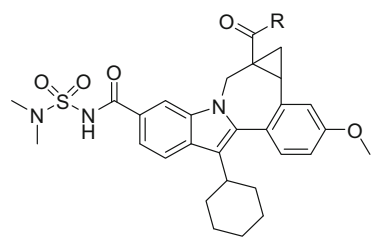

\begin{tabular}{|c|c|c|c|c|c|c|}
\hline Compound & $\mathrm{R}$ & $\begin{array}{l}1 \mathrm{~b} \\
(\text { FRET) } \\
\mathrm{EC}_{50} \\
(\mu \mathrm{M}) \\
\end{array}$ & $\begin{array}{l}1 \mathrm{a} \\
(\mathrm{FRET}) \\
\mathrm{EC}_{50} \\
(\mu \mathrm{M})\end{array}$ & $\begin{array}{l}1 \mathrm{~b} \\
(\mathrm{FRET})+40 \% \\
\text { serum } \mathrm{EC}_{50} \\
(\mu \mathrm{M})\end{array}$ & $\begin{array}{l}\text { Cytotoxicity } \\
\mathrm{CC}_{50}(\mu \mathrm{M})\end{array}$ & $\begin{array}{l}\text { PXR- } \\
\text { TA } \\
\mathrm{EC}_{50} \\
(\mu \mathrm{M}) / \\
Y_{\max } \\
(\%)\end{array}$ \\
\hline 49 & & 0.038 & 0.045 & 0.059 & $>10$ & $\begin{array}{l}>50 / \\
\mathrm{ND}\end{array}$ \\
\hline 50 & & 0.020 & $* 0.014$ & 0.056 & $>10$ & $\begin{array}{l}>50 / \\
\mathrm{ND}\end{array}$ \\
\hline 51 & & 0.050 & $* 0.015$ & 0.115 & $>10$ & $>3 / 32$ \\
\hline 52 & & $* 0.023$ & $*<0.014$ & 0.065 & $* 6.5$ & $>50 / 14$ \\
\hline 53 & & 0.029 & $*<0.014$ & 0.068 & $>10$ & $>50 / 12$ \\
\hline 54 & & $* 0.16$ & $* 0.068$ & ND & $* 8$ & $>50 / 10$ \\
\hline 55 & & $* 0.22$ & $* 0.054$ & ND & $* 7$ & $>50 / 3$ \\
\hline
\end{tabular}

* $\mathrm{EC}_{50}$ values marked with an asterisk are derived from a single experiment run in duplicate; other values represent the mean of $>2$ test occasions. $N D$ not determined. All compounds listed were tested as racemic mixtures

higher liver levels of $9.6 \mu \mathrm{M}$, and a reduced clearance of $14 \mathrm{~mL} / \mathrm{min} / \mathrm{kg}$ following IV administration. However, in the oral leg of the study, the liver levels of $\mathbf{5 0}$ fell to $3.7 \mu \mathrm{M}$ at the $4 \mathrm{~h}$ time point and were actually lower than that observed with 49 $(8.8 \mu \mathrm{M})$. Additionally, the plasma AUC was equally disappointing. Collectively, 
Table 6 Metabolic stability and profiling studies of azetidine carboxamides

\begin{tabular}{l|l|l|l}
\hline Compound & $\begin{array}{l}\text { PAMPA Pc }(\mathrm{nm} / \mathrm{s}) \text { at } \\
\text { pH 7.4 }\end{array}$ & $\begin{array}{l}\text { Microsome stability \% remaining } \\
\text { human/rat }\end{array}$ & $\begin{array}{l}\text { Amorphous solubility } \\
(\mu \mathrm{g} / \mathrm{mL})\end{array}$ \\
\hline $\mathbf{4 9}$ & 250 & $95 / 84$ & 57 \\
\hline $\mathbf{5 0}$ & 300 & $81 / 85$ & 93 \\
\hline $\mathbf{5 1}$ & 470 & $100 / 100$ & ND \\
\hline $\mathbf{5 2}$ & 740 & $72 / 100$ & ND \\
\hline $\mathbf{5 3}$ & 190 & $100 / 100$ & ND \\
\hline $\mathbf{5 4}$ & 390 & $72 / 100$ & ND \\
\hline $\mathbf{5 5}$ & ND & $87 / 100$ & ND \\
\hline
\end{tabular}

The permeability data used in this and following studies were generated using a parallel artificial membrane permeability (PAMPA) assay, and the solubilities of selected amorphous analogs were assessed in phosphate buffer at $\mathrm{pH} 6.5$ [43]. Additionally, the metabolic stabilities of members of the class were initially profiled in human and rat liver microsomes, and for more advanced analogs, against a broader range of species [44]

$N D$ not determined. All material listed were tested as racemic mixtures

Table 7 Rat PK parameters ( 0 to $4 \mathrm{~h}$ ) associated with azetidine carboxamides

\begin{tabular}{|c|c|c|c|c|c|c|c|}
\hline Compound & $\begin{array}{l}\text { IV AUC } \\
0-4 \mathrm{~h} \\
(\mathrm{nM} \mathrm{h})\end{array}$ & $\begin{array}{l}\mathrm{Cl} \text { (est.) } \\
(\mathrm{mL} / \mathrm{min} / \\
\mathrm{kg})\end{array}$ & $\begin{array}{l}4 \mathrm{~h} \\
\text { plasma } \\
\text { IV (nM) }\end{array}$ & $\begin{array}{l}4 \mathrm{~h} \text { liver } \\
\text { IV } \\
(\mathrm{nM})\end{array}$ & $\begin{array}{l}\text { PO AUC } \\
0-4 \mathrm{~h} \\
(\mathrm{nM} \mathrm{h})\end{array}$ & $\begin{array}{l}4 \mathrm{~h} \\
\text { plasma } \\
\text { PO (nM) }\end{array}$ & $\begin{array}{l}4 \mathrm{~h} \\
\text { liver } \\
\mathrm{PO} \\
(\mathrm{nM})\end{array}$ \\
\hline 49 & 1,416 & 96 & 17 & 5,000 & 41 & 11 & 8,800 \\
\hline 50 & 9,800 & 14 & 29 & 9,600 & 139 & 25 & 3,700 \\
\hline
\end{tabular}

Values are the average of the data from two animals. Vehicle, 100\% PEG400. IV and PO dosing was conducted at 5 and $10 \mathrm{mg} / \mathrm{kg}$, respectively

these data were considerably removed from what was considered necessary of a candidate for clinical evaluation.

With improved insights on the limitations of the lipophilic carboxamides that had been explored to this point, in a key decision, attention was directed toward the assessment of a more hydrophilic series of piperazine carboxamides. These retained the topology of the prior morpholine analogs but, as zwitterions, were significantly more polar and offered the possibility of evaluating a range of salt forms. Furthermore, the piperazine moiety facilitated rapid development of a systematic, progressive SAR as illustrated by the selected examples shown in Table 8.

Within this series it was found that analogs that retained a basic nitrogen, such as in 51 and 52, were generally among the most potent derivatives identified, approaching the activity of the previously discussed ether-appended morpholine 46. In addition, unlike the morpholine compounds, all of the piperazine carboxamides were devoid of significant effects in the hPXR transactivation assay [36]. This was true even with the basic derivatives $\mathbf{5 1}$ and $\mathbf{5 2}$, an observation that might be rationalized by appreciating that under physiological (or assay) conditions, the distal nitrogen of the piperazine would be expected to be partly protonated, thus preventing the presentation of a Lewis base element. More disappointing, however, was the finding that the 

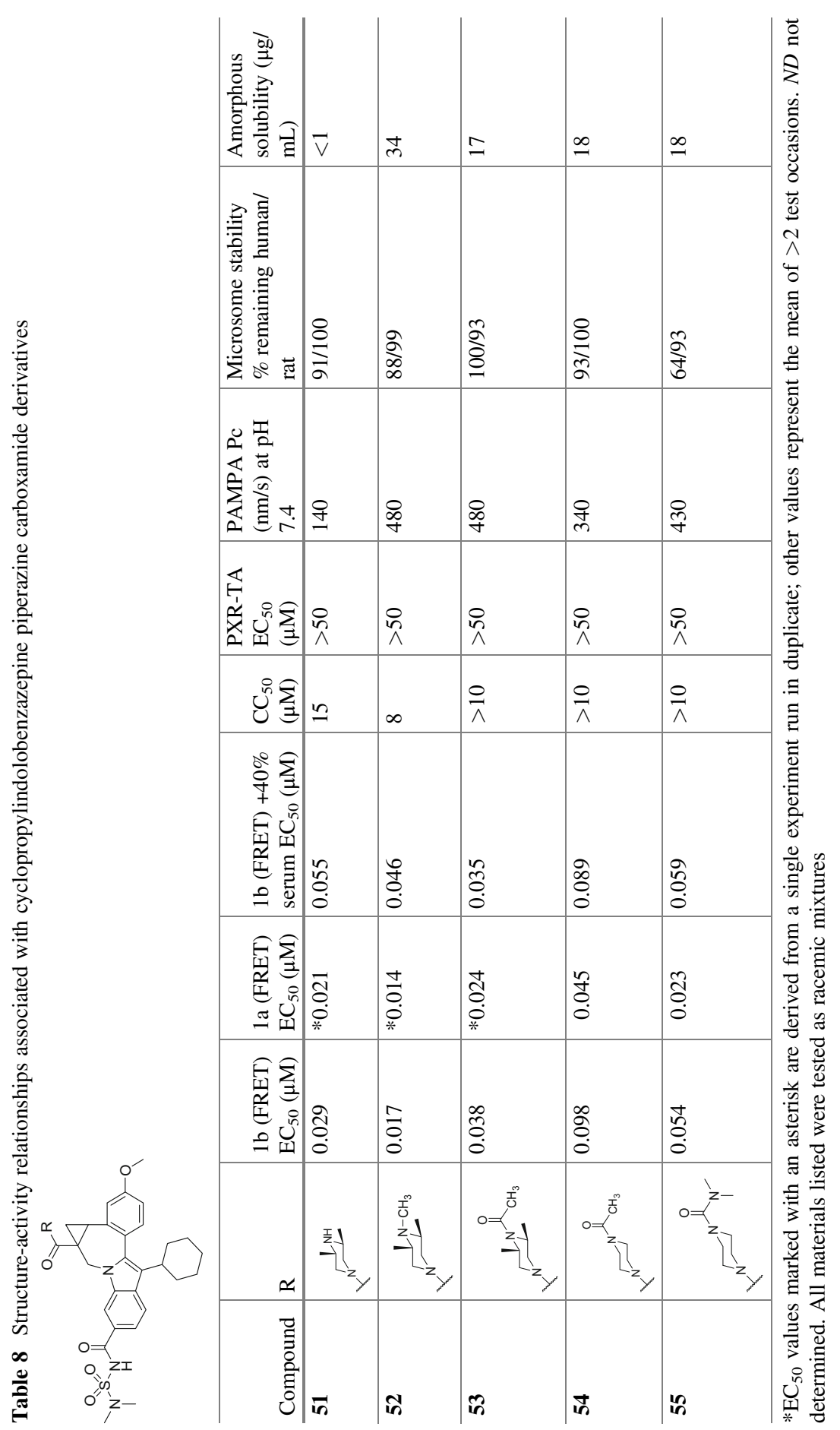
introduction of additional charged or polar groups at this vector did not generally result in improved solubility. However, as zwitterions, more complex $\mathrm{pH}$-dependent solubility profiles would be expected, and, as discussed, these compounds offered the possibility of exploring alternative salt forms, a feature that was thoroughly evaluated with these and related analogs [46].

In profiling studies, the piperazines $\mathbf{5 2}$ and $\mathbf{5 3}$ exhibited a significantly enhanced metabolic stability and permeability properties. It was considered that these improvements would partly address the issues seen with the two azetidines 49 and 50, and both were progressed into $4 \mathrm{~h}$ rat PK screens, the results from which are shown in Table 9.

In the case of the $N$-acetyl derivative $\mathbf{5 3}$, there was no translation into an enhanced exposure profile. This, combined with an observed reduction in liver tropism, led to the deprioritization of this class. Of much greater significance, however, was the data obtained on the zwitterionic derivative 52. This analog displayed decidedly improved plasma AUC and liver levels (PO), findings that were attributed to the improved balance of permeability (Pc $480 \mathrm{nM} / \mathrm{s}$ ) and solubility $(34 \mu \mathrm{g} / \mathrm{mL})$. Given that this analog was also among the most potent identified, it was immediately prioritized for further investigation.

In the attendant studies, an initial design prioritized analogs that retained a basic character at the N4-position of the piperazine. In addition, novel structural elements that would induce further conformation constraints were incorporated. This revisited one of the original concepts associated with the introduction of the cyclopropyl moiety, and as it could be achieved without dramatically impacting the overall silhouette of the chemotype, priority was given to the syntheses of the analogs compiled in Table 10.

The data obtained with these derivatives proved to be of immense value. With the proximal methano- and ethano-bridged derivatives 58,59 , and 66 , clinically relevant potencies of $<10 \mathrm{nM}$ against the targeted genotypes were achieved. This was in contrast to the distally bridged congeners that were consistently less potent. Additionally, there appeared to be steric limitations associated with the N4 nitrogen of the carboxamide moieties, with larger substituents displaying reduced potencies and, in the case of aromatic functionality, a reemergence of prior hPXR issues.

While all of the bridged piperazines possessed good metabolic stability in liver microsomes, they displayed a significant variation in their permeability properties. The N4-alkylated, proximally bridged derivatives 58, 65, and $\mathbf{6 6}$ all exhibited

Table 9 Rat PK parameters ( 0 to 4 h) associated with piperazine carboxamides

\begin{tabular}{|c|c|c|c|c|c|c|c|}
\hline Compound & $\begin{array}{l}\text { IV AUC } \\
0-4 \mathrm{~h} \\
(\mathrm{nM} \mathrm{h})\end{array}$ & $\begin{array}{l}\mathrm{Cl} \text { (est.) } \\
(\mathrm{mL} / \mathrm{min} / \\
\mathrm{kg})\end{array}$ & $\begin{array}{l}4 \mathrm{~h} \\
\text { plasma } \\
\text { IV (nM) }\end{array}$ & $\begin{array}{l}4 \mathrm{~h} \text { liver } \\
\mathrm{IV} \\
(\mathrm{nM})\end{array}$ & $\begin{array}{l}\text { PO AUC } \\
0-4 \mathrm{~h} \\
(\mathrm{nM} \mathrm{h})\end{array}$ & $\begin{array}{l}4 \mathrm{~h} \\
\text { plasma } \\
\text { PO }(\mathrm{nM})\end{array}$ & $\begin{array}{l}4 \mathrm{~h} \\
\text { liver } \\
\mathrm{PO} \\
(\mathrm{nM}) \\
\end{array}$ \\
\hline 52 & 4,287 & 29 & 67 & 1858 & 516 & 158 & 9,700 \\
\hline 53 & 3,841 & 37 & 9 & 126 & 277 & 14 & 345 \\
\hline
\end{tabular}

Values are the average of the data from two animals. Vehicle, 100\% PEG400. IV and PO dosing was conducted at 5 and $10 \mathrm{mg} / \mathrm{kg}$, respectively 


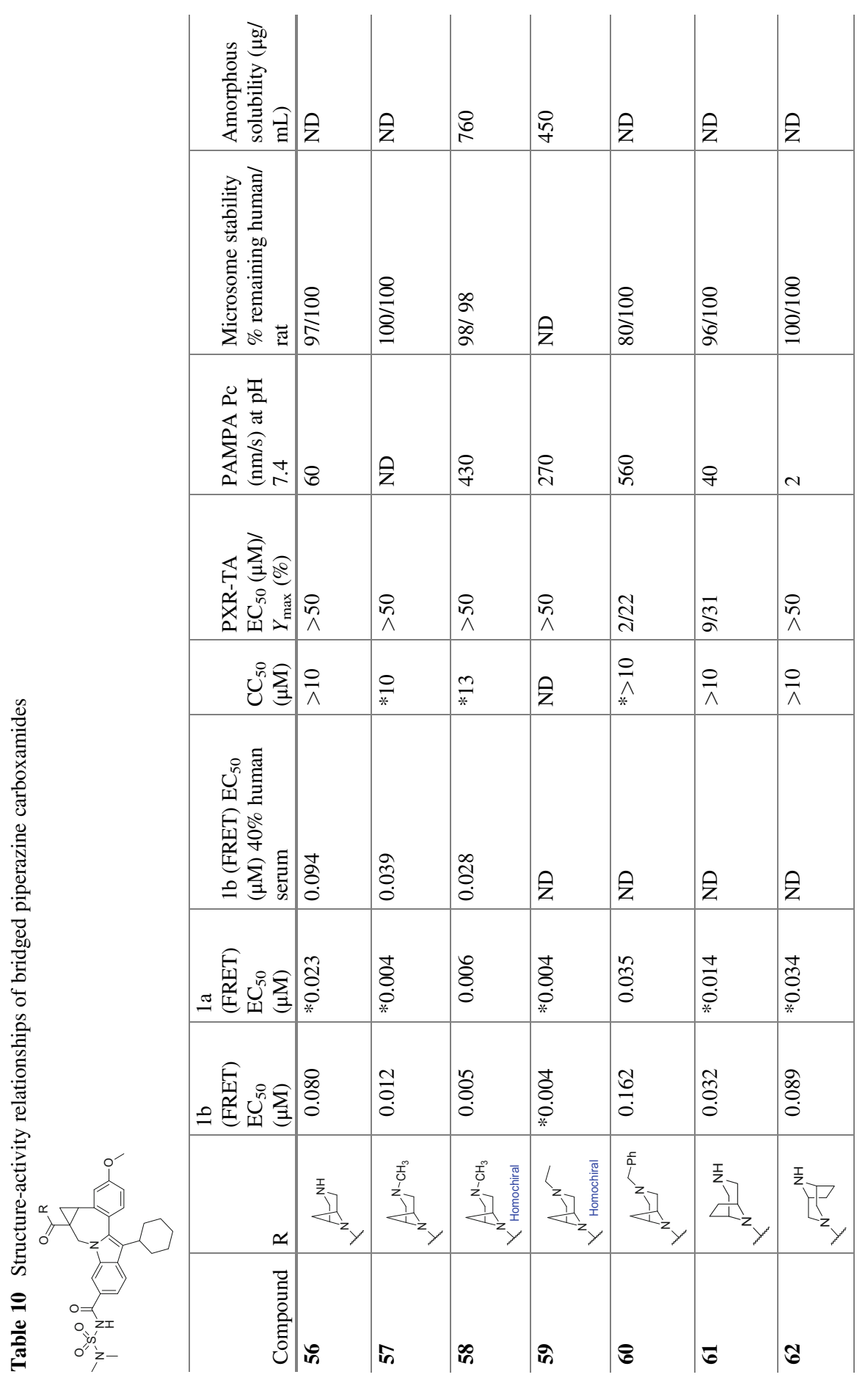




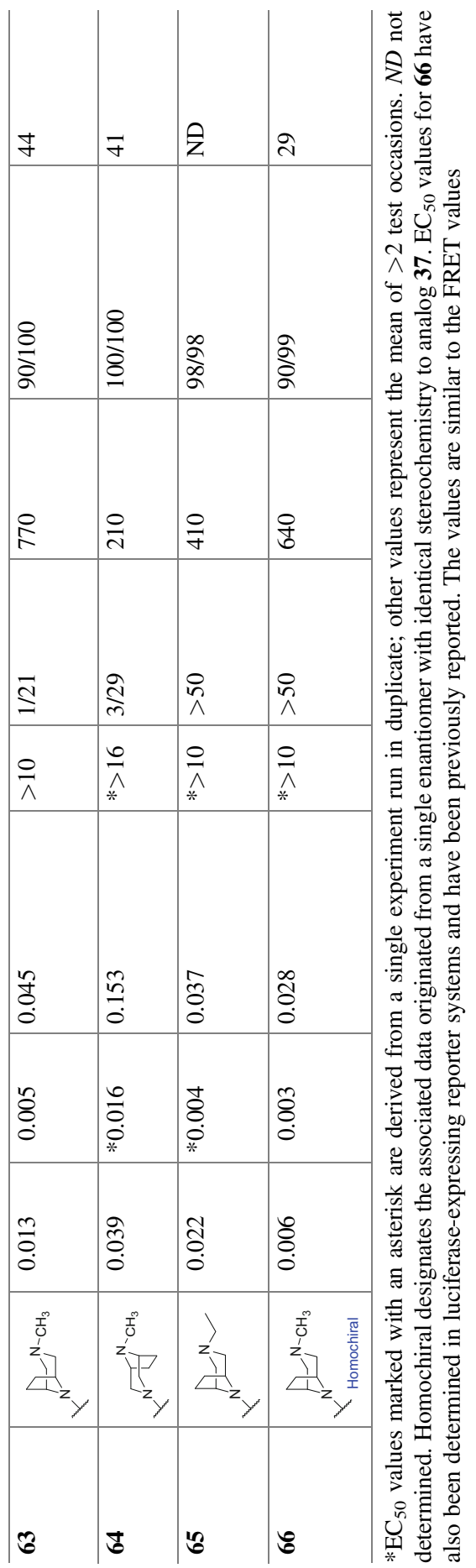


excellent membrane permeability values; this was in contrast to the permeability properties shown by the non-alkylated and distally bridged derivatives. Another source of differentiation within the series related to amorphous solubility, with the methano-bridged analogs $58(760 \mu \mathrm{g} / \mathrm{mL})$ and $\mathbf{5 9}(450 \mu \mathrm{g} / \mathrm{mL})$ clearly distinguishing themselves. However, given the amorphous nature of the materials assessed in these assays, the significance of these data was challenging to interpret [47]. Nonetheless, given the overall properties of compound 58, this analog was advanced into a $6 \mathrm{~h}$ rat PK study, the data from which are shown in Table 11.

Very encouragingly, $\mathbf{5 8}$ exhibited lower clearance, markedly higher oral and IV plasma AUCs, and improved liver levels throughout the extended $6 \mathrm{~h}$ time period. This, together with the collective data from Table 10, drove the further characterization of these methano analogs in an expanded set of liability assays. Selected data for compounds $\mathbf{5 8}$ and $\mathbf{5 9}$ are presented Table 12 and are representative of many of the members of this series.

Cytotoxicity in a liver Hep G2 cell line was observed but was weak, and a significant selectivity index existed with a majority of the analogs explored. In cytochrome P450 inhibition assays, only moderate, sporadic inhibitory activities against a panel of isozymes were noted, but of more concern were the variable levels of inhibitory activities observed in the ion channel screens [48]. While the majority of analogs in the bridged piperazines displayed little to no effect at the hNaV1.5 sodium channel (expressed in HEK cells), single-digit micromolar inhibition of the human ether-à-go-go (hERG) channel was observed, as can be seen with $\mathbf{5 9}$ above, a compound that also exhibited single-digit micromolar inhibition of the CYP3A4 enzyme [49].

Contrasting the ethano- and methano-bridged derivatives allowed a study of the effect of transposition and homologation of the bridging element. Within the ethano series, relocation of the bridge from a proximal to a distal position relative to the

Table 11 Rat PK profile of indolobenzazepine 58 (0-6 h post-dosing)

\begin{tabular}{|c|c|c|c|c|c|c|c|}
\hline Compound & $\begin{array}{l}\text { IV AUC } \\
0-6 \mathrm{~h} \\
(\mathrm{nM} \mathrm{h})\end{array}$ & $\begin{array}{l}\mathrm{Cl} \text { (est.) } \\
\text { (mL/min/ } \\
\mathrm{kg})\end{array}$ & $\begin{array}{l}6 \mathrm{~h} \\
\text { plasma } \\
\text { IV (nM) }\end{array}$ & $\begin{array}{l}6 \mathrm{~h} \text { liver } \\
\text { IV } \\
(\mathrm{nM})\end{array}$ & $\begin{array}{l}\text { PO AUC } \\
0-6 \mathrm{~h} \\
(\mathrm{nM} \mathrm{h})\end{array}$ & $\begin{array}{l}6 \mathrm{~h} \\
\text { plasma } \\
\text { PO }(\mathrm{nM})\end{array}$ & $\begin{array}{l}6 \mathrm{~h} \\
\text { liver } \\
\mathrm{PO} \\
(\mathrm{nM})\end{array}$ \\
\hline 58 & 11,200 & 9 & 409 & 17,500 & 4,930 & 440 & 14,300 \\
\hline
\end{tabular}

Values are the average of the data from two animals. Vehicle, 100\% PEG400. IV and PO dosing was conducted at 5 and $10 \mathrm{mg} / \mathrm{kg}$, respectively

Table 12 Profiling studies of cyclopropylindolobenzazepine-bridged piperazine carboxamides

\begin{tabular}{l|l|l|l|l|l|l|l|l}
\hline & Hep & & & CYP & CYP & CYP & CYP & \\
& G2 & hERG & NACH & $1 \mathrm{~A} 2$ & 2 C9 & 2C19 & $2 \mathrm{D} 6$ & CYP 3A4 \\
Compound & $(\mu \mathrm{M})$ & $\begin{array}{l}\mathrm{IC}_{50} \\
(\mu \mathrm{M})\end{array}$ & $\begin{array}{l}\mathrm{IC}_{50} \\
(\mu \mathrm{M})\end{array}$ & $\begin{array}{l}\mathrm{IC}_{50} \\
(\mu \mathrm{M})\end{array}$ & $\begin{array}{l}\mathrm{IC}_{50} \\
(\mu \mathrm{M})\end{array}$ & $\begin{array}{l}\mathrm{IC}_{50} \\
(\mu \mathrm{M})\end{array}$ & $\begin{array}{l}\mathrm{IC}_{50} \\
(\mu \mathrm{M})\end{array}$ & $\begin{array}{l}\mathrm{BC}_{50}(\mu \mathrm{M}) \\
\mathrm{IC})\end{array}$ \\
\hline $\mathbf{5 8}$ & 25 & 20 & 30 & $>40$ & $>40$ & $>40$ & $>40$ & 14 \\
\hline $\mathbf{5 9}$ & 19 & 6 & 29 & $>40$ & $>40$ & $>40$ & $>40$ & 9 \\
\hline
\end{tabular}

Values are the average from at least two experiments 
carboxamide nitrogen was associated with a modest reduction in potency, as can be seen by comparing 61 to 62 and 63 to 64 . Additionally, homologation of the bridging element was associated with enhanced permeability as evidenced by the higher Pc values exhibited by the ethano analogs 65 and 66 (Pc values of 410 and $640 \mathrm{nM} / \mathrm{s}$, respectively), compared to their lower homologs $\mathbf{5 9}$ and $\mathbf{5 8}$ (Pc values of 270 vs. $430 \mathrm{nM} / \mathrm{s}$, respectively). Furthermore, a signal in the hPXR transactivation assay associated with the racemic ethano-bridged $\mathrm{N}$-methyl analog 63 was notably absent from the highly potent, resolved enantiomer 66 [36].

With many of the bridged piperazines, significant advances in both the on- and off-target profiles of the compounds had been realized. In particular, as a result of the excellent level of activity achieved with $\mathbf{6 6}$, and its enhanced membrane permeability and profiling properties relative to $\mathbf{5 8}$, this compound was rapidly advanced into additional profiling and PK studies, as well as efforts to further understand its broader toxicological and virological profiles.

The zwitterionic form of $\mathbf{6 6}$ (pKa values $=4.6$ and 6.8) was amorphous and displayed $\mathrm{pH}$-dependent aqueous solubility of between $\sim 0.02 \mathrm{mg} / \mathrm{mL}$ and greater than $1.60 \mathrm{mg} / \mathrm{mL}$. The compound was highly permeable, as determined in a PAMPA assay, but exhibited efflux ratios in a Caco-2 system that increased from 2.2 at $\mathrm{pH}=5.5$ to 8.3 at $\mathrm{pH}=7.4$ [50]. It was surmised that the lower efflux ratio expected in the gut could be accommodated, and the higher efflux ratio seen at $\mathrm{pH}=7.4$ would preclude any uptake into the central nervous system (CNS) and would therefore limit any unwanted neurological effects. The metabolic stability of this compound was also evaluated in an expanded panel of liver microsomes that included human, rat, dog, and cynomolgus monkey. Half-life values of $>200 \mathrm{~min}$ were observed in both the rat and dog assays, while in human and monkey microsomes, the $t_{1 / 2}$ values were 53 and 23 min, respectively. Collectively, these data were highly supportive of the continued evaluation of 66, which was subsequently progressed into $24 \mathrm{~h}$ rat PK studies, the data from which are presented in Table 13.

From these investigations the oral bioavailability of $\mathbf{6 6}$ was determined to be $66 \%$ when dosed as a solution in PEG-400. The compound was well distributed, having a volume of distribution of $2.7 \mathrm{~L} / \mathrm{kg}$. It exhibited low-clearance $(3.5 \mathrm{~mL} / \mathrm{min} / \mathrm{kg})$ characteristics following an IV dose as a solution in PEG-400, a finding consistent with the stability observed in rat liver microsomes. These properties led to a plasma half-life of $8.3 \mathrm{~h}$ and, importantly, liver levels (evaluated in a satellite study (in two rats) measured at both 4 and $24 \mathrm{~h}$ following oral dosing) of $24,400 \mathrm{nM}$ and $1,700 \mathrm{nM}$, respectively. These represented significant multiples of the serumadjusted replicon $\mathrm{EC}_{50}$ values.

In vivo biotransformation studies showed that $\mathbf{6 6}$ generated one principal circulating metabolite that arose from mono-demethylation of the sulfamide moiety [51]. Profiling of this species showed that it retained a significant antiviral activity but was otherwise benign and did not constitute a liability. The overall profile exhibited by $\mathbf{6 6}$ was largely mirrored in other species in which it was evaluated, and with these findings, the primary criteria for nomination of a clinical candidate had been achieved. 


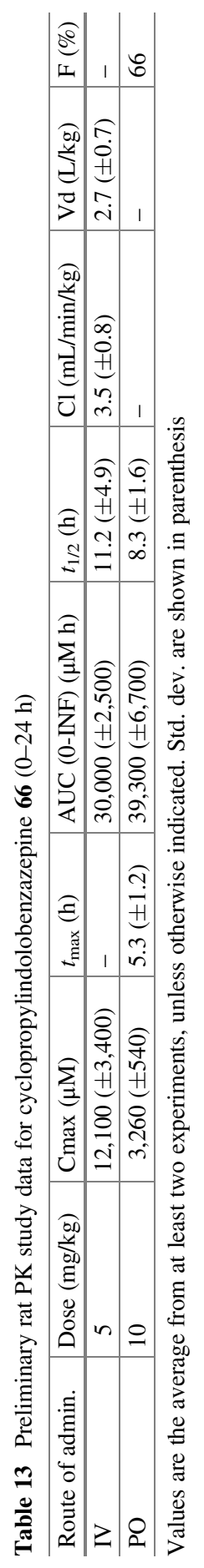


As the compound progressed through the above studies, additional effort was directed at more fully characterizing the virological and toxicological profiles. In relation to the former, compound $\mathbf{6 6}$ was evaluated against a range of HCV genotypes, in both enzyme and replicon assays, the results from which are shown in Table 14. As previously noted (vide supra), the primary goal was inhibition of genotypes 1a and 1b; however, it was highly encouraging that $\mathbf{6 6}$ displayed an activity against most genotypes tested with the exceptions of $2 a, 2 b$, and $6 a$. Since genotypes $2 \mathrm{a}$ and $2 \mathrm{~b}$ responded well to what was the optimal treatment for $\mathrm{HCV}$ at the time of these discoveries, and the fact that genotype 6 was of lower prevalence, the antiviral activity exhibited by this indolobenzazepine was considered supportive of further advancement.

In viral selectivity studies used to assess non-specificity of action, the activity of 66 was evaluated against a panel of viruses that included the HCV-related bovine viral diarrhea virus (BVDV), as well as polio, rhino, corona, coxsackie, influenza, and human immunodeficiency viruses (HIV) [52]. In all of these assays, 66 was found to be essentially inactive $\left(\mathrm{EC}_{50}\right.$ value $\left.>14 \mu \mathrm{M}\right)$ and therefore likely to be highly specific in its mechanism of action.

Given the sporadic cytotoxicity seen with some members of the compound class, 66 was profiled in cell lines derived from a number of tissues. While effects were seen in some cells with $\mathrm{CC}_{50}$ values in the range of 14 to more than $48 \mu \mathrm{M}$, given the potency of 66 in the $\mathrm{HCV}$ genotype $1 \mathrm{~b}$ replicon, there existed selectivity indices in excess of 2000. It was therefore concluded that the toxicity signals observed were unlikely to be of clinical relevance.

To further characterize potential off-target effects, $\mathbf{6 6}$ was evaluated in a panel of receptor and ion channel binding and enzyme inhibition assays (https://www.mdsps. $\mathrm{com} /$ ). In these studies, there were no significant findings other than a moderate inhibition of human phosphodiesterase 4 . This activity was explored in a functional assay where it was determined that 66 had an $\mathrm{IC}_{50}$ value in excess of $10 \mu \mathrm{M}$. Given this moderate level of activity, coupled with a low potential for uptake into the CNS (vide supra), it was assessed that there was limited risk for induction of emesis [53]. In studies designed to assess cardiac liabilities, 66 was profiled in a hERG patch-clamp assay and was determined to inhibit the channel with an $\mathrm{IC}_{50}$ value of $12.4 \mu \mathrm{M}(n=1)$. This was considered acceptable given that the compound was highly bound (98\%) to human serum, and the anticipated doses would not result in a circulating free fraction that would approach this concentration (additional studies were undertaken to confirm this hypothesis but are not reviewed here).

As 66 was designed to be administered as part of a combination therapy, it was necessary to fully assess the potential for DDIs. Correspondingly, it was profiled for CYP inhibition in a panel incorporating 1A2, 2C19, 2C9, 2D6, and 3A4 enzymes and displayed $\mathrm{IC}_{50}$ values of $>40 \mu \mathrm{M}$ (based on the average of three determinations), suggesting a low probability for inducing DDIs through cytochrome P450 inhibition. In addition, when assessed in the hPXR transactivation assay, the compound displayed a minimal activity $\left(\mathrm{EC}_{50}>50 \mu \mathrm{M}, Y_{\max }=8.1 \pm 1.9\right.$ at $\left.5.56 \mu \mathrm{M}\right)$, again suggesting a low potential for autoinduction of metabolism and attendant DDI potential. 


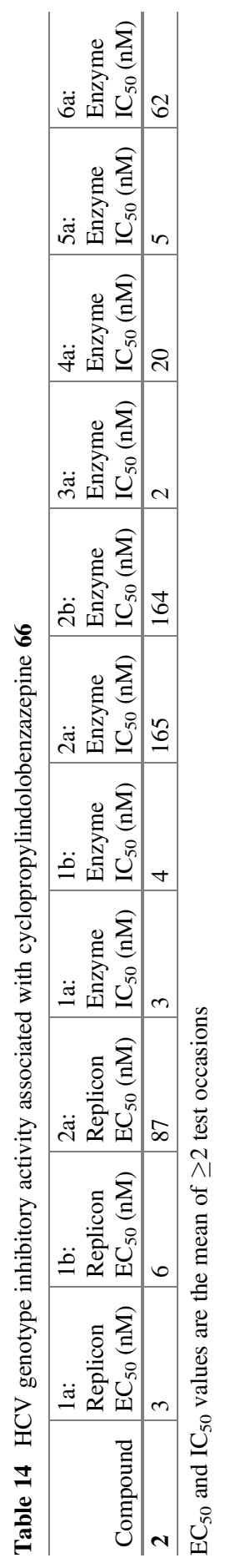


Although not directly related to the clinical advancement of compound $\mathbf{6 6}$, a number of structural and mechanistic studies were undertaken. These included obtaining an X-ray structure of a co-crystal of $\mathbf{6 6}$ bound to NS5B [54]. Consistent with prior investigations of the bridged indole chemotypes, the compound was observed to bind in Site I of the thumb domain of the polymerase, as depicted graphically in Fig. 15. Importantly, the data acquired in these experiments were used to assign the absolute stereochemistry of $\mathbf{6 6}$ and, by extension, that of the other cyclopropylindolobenzazepines presented here.

From these data, 66 can be seen to occupy a largely hydrophobic binding site, with the polar elements of the molecule mostly protruding into an aqueousaccessible compartment. The primary drivers of binding are interactions between the cyclohexyl, phenyl, and indole elements of the molecule with hydrophobic amino acid side chains in the binding site, in combination with $\mathrm{H}$-bonds between the sulfamide moiety and R503. Additional contacts between the methylene moiety of the cyclopropyl ring and the ethano-bridged N-methyl piperazine group and the proximal L492, T399, and A400 residues also contribute to binding affinity. Significantly, P495 is seen to make multiple contacts with the indole ligand, explaining the reduced activity of $\mathbf{6 6}$ in assays utilizing the P495A and $\mathrm{P} 495 \mathrm{~L}$ mutant NS5B proteins (e.g., $\mathrm{IC}_{50} \mathrm{WT} 1 \mathrm{~b} / \mathrm{P} 495 \mathrm{~L}=0.02 / 0.19 \mu \mathrm{M}$ ). Returning to a point made first when introducing the bridged indole chemotype, the dihedral angle between the fused methoxyaryl moiety and the indole ring in 66 is $44^{\circ}$; this approximates that seen for the same dihedral $\left(43^{\circ}\right)$ in compound 14 , the analog that was the essential precursor for most of the work that was described subsequently [23].

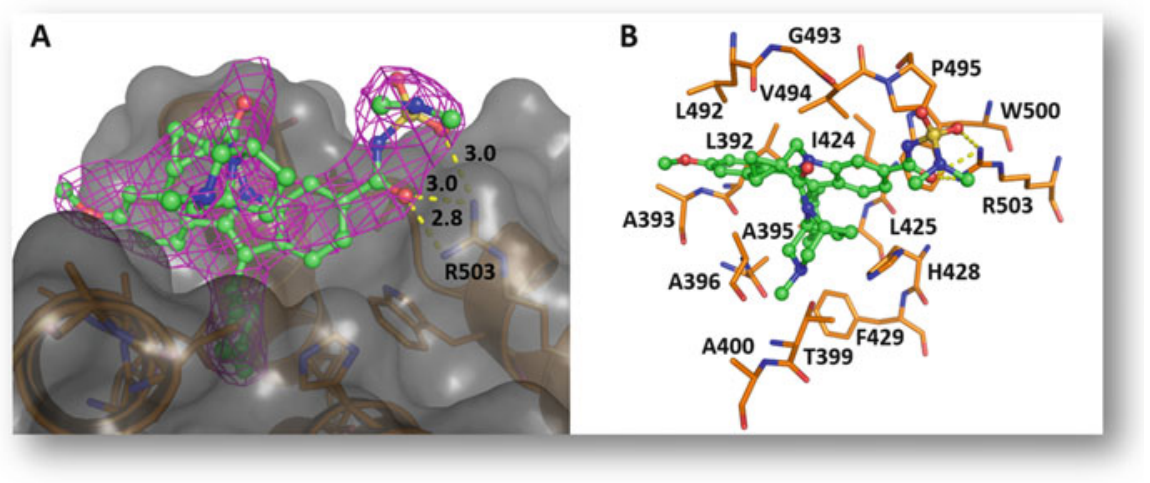

Fig. 15 (a) The Connolly surface of NS5B with compound 66 bound in Site I [55]. (b) Detailed view of residues (stick representation, orange carbon atoms) proximal to bound $\mathbf{6 6}$ (ball-and-stick representation, green carbon atoms). Data derived from the co-crystal structure of the ternary complex of 66 (thumb site, shown), a palm site inhibitor (not shown), and NS5B determined to $2.75 \AA$ resolution. Hydrogen bonds are denoted with dashed yellow lines, and the initial $2 \mathrm{Fo}-\mathrm{Fc}$ electron density for $\mathbf{6 6}$ is shown as a magenta mesh, contoured at $1 \mathrm{rmsd}$. All distances are in angstroms. Images created with PyMOL (The PyMOL Molecular Graphics System, Version 2.0 Schrödinger, LLC) 
The mode of binding observed with $\mathbf{6 6}$ suggests an explanation for its probable mechanism of action, where occupation of a lipophilic pocket in the thumb domain of NS5B is believed to prevent the enzyme from adopting a transcriptionally active conformation, as outlined below [56].

This putative inhibition mechanism is depicted graphically in Fig. 16. In the apo structure shown in Panel A, Leu-30 of the $\Delta 1$ loop of NS5B is observed to occupy the same pocket into which the cyclohexyl moiety of $\mathbf{6 6}$ inserts when it binds to the enzyme, as shown in Panel B. It is thought that Leu-30 occupies this pocket during transcription of the viral genome and that this interaction contributes to the stabilization of the transcriptionally active, "closed" conformation. However, when this residue is displaced by the binding of compound 66, the enzyme can no longer adopt this conformation, and viral replication is prevented. Consistent with this hypothesis, kinetic studies indicate that the $\Delta 1$ finger domains interact dynamically with Site I in the thumb domain and appear to compete with $\mathbf{6 6}$ during its initial binding to NS5B [56].

To conclude the discussion of the preclinical characterization of compound $\mathbf{6 6}$, the data reviewed above met or exceeded the goals for nomination of a clinical candidate, and 66, also known as BMS-791325, was accepted for advancement into early development during which time it acquired its generic nomenclature of beclabuvir (BCV).

In Phase 1 clinical studies, the pharmacokinetics, safety, and antiviral profiles of 66 were assessed in a double-blind, placebo-controlled, single-ascending-dose (SAD) study [57]. Twenty-four patients with chronic HCV genotype 1 infection,

A

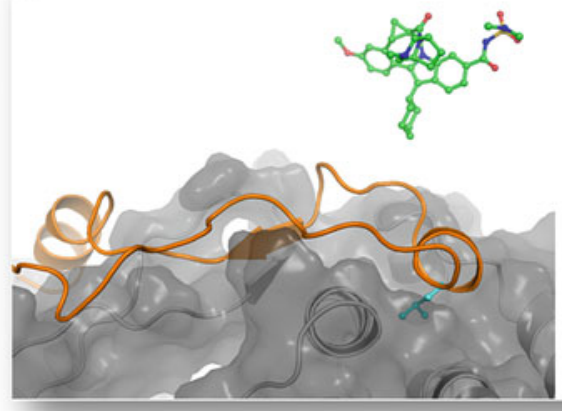

B

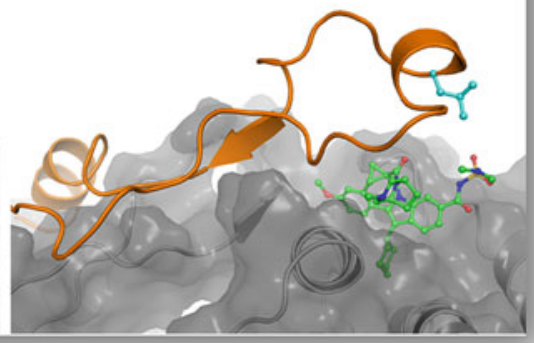

Fig. 16 Possible mechanism of inhibition of NS5B by compound 66. In both figures the indolobenzazepine ligand and residue Leu-30 of NS5B are shown in ball-and-stick representations with green- and cyan-colored carbon atoms, respectively. Residues 1-53 of NS5B are depicted in orange, and the remainder of the protein is shown with gray schematic and surface representations. Panel (a) shows the apo crystal structure of NS5B (Protein Data Bank code 1C2P) together with unbound 66. Panel (b) the conformation shown for residues 1-53 (orange) of NS5B is for illustrative purposes only. Compound $\mathbf{6 6}$ is shown in its correct bound pose. Images created with PyMOL (The PyMOL Molecular Graphics System, Version 2.0 Schrödinger, LLC) 
including both INF-naïve and INF-experienced groups, were randomized to receive ascending doses of 100, 300, 600, and $900 \mathrm{mg}$ of $\mathbf{6 6}$ or placebo. Antiviral activity was observed in all dose groups, with those patients receiving the $300 \mathrm{mg}$ dose exhibiting an approximately $2.5 \log _{10} \mathrm{IU} / \mathrm{mL}$ decline in viral load measured $24 \mathrm{~h}$ post-dosing. Single doses of $\mathbf{6 6}$ exhibited dose-related increases in exposure, demonstrated rapid and exposure-related antiviral activity, and were well tolerated. The established pharmacokinetic profiles were supportive of once- or twice-daily dosing.

As noted in the introduction to this chapter, the intended use of an NS5B inhibitor was in combination with other DAAs of unrelated mechanisms of action. To that end, $\mathbf{6 6}$ was investigated in a fixed-dose combination (termed DCV-TRIO) with the NS5A inhibitor daclatasvir (DCV) (67) and the NS3 protease inhibitor asunaprevir (ASV) (68) [58-60] in a clinical program designated UNITY. The Phase 3 studies [61] investigated the use of DCV-TRIO in both cirrhotic and non-cirrhotic patients infected with $\mathrm{HCV}$ genotype 1 for a period of 12 weeks.

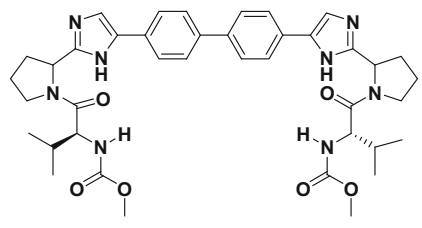

67

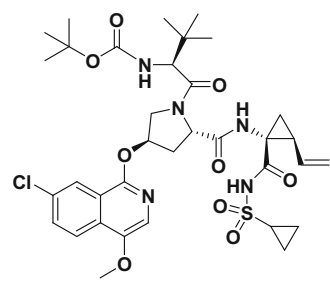

68

In the open-label UNITY-1 study, DCV-TRIO was dosed without ribavirin in both treatment-naïve and treatment-experienced non-cirrhotic patients. The treatment-naïve group $(n=312)$ and the treatment-experienced patients $(n=103)$ received one pill twice daily for 12 weeks with 24 weeks of follow-up. SVR12 was achieved by $91 \%$ of all treated patients.

In the UNITY-2 study, treatment-naïve and treatment-experienced patients with cirrhosis received the DCV-TRIO fixed-dose combination, one arm without ribavirin $(n=102)$ and the other with ribavirin $(n=100)$. SVR12 rates of $96 \%$ or $90 \%$ were achieved by patients treated with DCV-TRIO with or without ribavirin, respectively [62].

In these studies the DCV-TRIO fixed-dose combination was well tolerated with very low rates of both adverse events (AEs) and serious adverse events (SAEs) reported. Only in the UNITY-2 study were there treatment-related AEs (4) and SAEs (3) that subsequently led to treatment discontinuations.

In relation to $\mathrm{BCV}$ and its development as a component of the DCV-TRIO formulation, later termed Ximency, clinical trials were directed at gaining approval in Japan. These included a Japanese Phase 3 study (AI443117) [63], a global Phase 1 study (AI443006) [64] in healthy Japanese subjects, a Phase 1 study (AI443112) [65] on the effect on QT interval, and a proof-of-concept study (AI443014) 
$[66,67]$. These were used as to support a Japanese new drug application that was subsequently approved by the Japanese Pharmaceutical and Food Safety Bureau in December 2016.

Acknowledgments The following individuals made invaluable contributions to the work described above: Min Ding, John Bender, Carl P. Bergstrom, Katherine Grant-Young, Piyasena Hewawasam, Thomas Hudyma, Scott Martin, Andrew Nickel, Alicia Regueiro-Ren, Yong Tu, Zhong Yang, Kap-Sun Yeung, Xiaofan Zheng, Sam Chao, Jung-Hui Sun, Brett R. Beno, Dan Camac, Chong-Hwan Chang, Mian Gao, Paul Morin, Steven Sheriff, Jeff Tredup, John Wan, Mark Witmer, Dianlin Xie, Umesh Hanumegowda, Jay Knipe, Kathy Mosure, Kenneth S. Santone, Dawn D. Parker, Xiaoliang Zhuo, Julie Lemm, Mengping Liu, Lenore Pelosi, Karen Rigat, Stacey Voss, Yi Wang, Ying-Kai Wang, Richard C. Colonno, Min Gao, Susan B. Roberts, Qi Gao, Alicia Ng, Nicholas A Meanwell, and John F. Kadow.

The author also thanks the following: Arvind Mathur and Bang-Chi Chen for their participation in multiple synthesis campaigns that enabled many of the above studies; Richard Rampulla and the chemists at Syngene International for synthesizing and providing numerous intermediates that greatly expedited much or the research reviewed; Brett Beno for his provision of several of the figures shown above; and Nicholas A. Meanwell, Fiona McPhee, and Richard Olson for proofreading this manuscript and for their many helpful suggestions.

\section{Compliance with Ethical Standards}

Funding The work described herein was funded by Bristol Myers Squibb as part of its routine business operations.

Conflict of Interest The author declares that he has no conflict of interest.

Ethical Approval This article does not contain any studies with human participants or animals performed by the author.

However, the work described does refer to a number of animal studies and subsequent human clinical studies conducted by others. With respect to those studies, all applicable international, national, and/or institutional guidelines for the care and use of animals were followed, and with respect to clinical studies, all were conducted in accordance with the ethical standards of the institutional and/or national research committee and with the 1964 Helsinki declaration and its later amendments or comparable ethical standards.

\section{References}

1. Meanwell NA (2016) 2015 Philip S. Portoghese Medicinal Chemistry Lectureship. Curing hepatitis $\mathrm{C}$ virus infection with direct-acting antiviral agents: the arc of a medicinal chemistry triumph. J Med Chem 59:7311-7351

2. Looney D, Ma Al, Johns S (2015) HIV therapy - the state of ART. Curr Top Microbiol Immunol 389:1-29

3. Borgia G, Maraolo AE, Nappa S, Gentile I, Buonomo AR (2018) NS5B polymerase inhibitors in phase II clinical trials for HCV infection. Expert Opin Investig Drugs 27(3):243-250

4. Tsai CH, Lee PY, Stollar V, Li ML (2006) Curr Pharm Des 12(11):1339-1355 
5. Dogan UB, Atabay A, Akin MS, Yalaki S (2013) The comparison of the efficacy of pegylated interferon $\alpha-2 \mathrm{a}$ and $\alpha-2 \mathrm{~b}$ in chronic hepatitis $\mathrm{C}$ patients with genotype 1. Eur J Gastroenterol Hepatol 25:1082-1085

6. Fontaine H, Pol S (2001) Side effects of interferon- $\alpha$ in treating hepatitis $\mathrm{C}$ virus infection. Transplant Proc 33:2327-2329

7. Shukla DD, Hoyne PA, Ward CW (1995) Evaluation of complete genome sequences and sequences of individual gene products for the classification of hepatitis $\mathrm{C}$ viruses. Arch Virol 140:1747-1761

8. Thurner C, Witwer C, Hofacker Ivo L, Stadler PF (2004) Conserved RNA secondary structures in Flaviviridae genomes. J Gen Virol 85:1113-1124

9. Sandres-Saune K, Deny P, Pasquier C, Thibaut V, Duverlie G, Izopet J (2003) Determining hepatitis C genotype by analyzing the sequence of the NS5b region. J Virol Methods 109:187-193

10. Davis GL (1999) Hepatitis C virus genotypes and quasispecies. Am J Med 107:21S-26S

11. Nolte FS (2001) Hepatitis C virus genotyping: clinical implications and methods. Mol Diagn 6:265-277

12. Rosenberg S (2001) Recent advances in the molecular biology of hepatitis C virus. J Mol Biol 313:451-464

13. Bressanelli S, Tomei L, Roussel A, Incitti I, Vitale RL, Mathieu M, De Francesco R, Rey FA (1999) Crystal structure of the RNA-dependent RNA polymerase of hepatitis C virus. Proc Natl Acad Sci U S A 96:13034-13039

14. Simister P, Schmitt M, Geitmann M, Wicht O, Danielson UH, Klein R, Bressanelli S, Lohmann V (2009) Structural and functional analysis of hepatitis C virus strain JFH1 polymerase. J Virol 83:11926-11939

15. Patil VM, Gupta SP, Samanta S, Masand N (2011) Current perspective of HCV NS5B inhibitors: a review. Curr Med Chem 18:5564-5597

16. Wang Y-K, Rigat KL, Roberts SB, Gao M (2006) A homogeneous, solid-phase assay for hepatitis C virus RNA-dependent RNA polymerase. Anal Biochem 359:106-111

17. Lemm JA, O’Boyle II D, Liu M, Nower PT, Colonno R, Deshpande MS, Snyder LB, Martin SW, St. Laurent DR, Serrano-Wu MH, Romine JL, Meanwell NA, Gao M (2009) Identification of hepatitis C virus NS5A inhibitors. J Virol 84:482-491

18. O’Boyle II DR, Nower PT, Lemm JA, Valera L, Sun J-H, Rigat K, Colonno R, Gao M (2005) Development of a cell-based high-throughput specificity screen using a hepatitis $\mathrm{C}$ virus-bovine viral diarrhea virus dual replicon assay. Antimicrob Agents Chemother 49:1346-1353

19. Pelosi LA, Voss S, Liu M, Gao M, Lemm JA (2012) Effect on hepatitis C virus replication of combinations of direct-acting antivirals, including NS5A inhibitor daclatasvir. Antimicrob Agents Chemother 56:5230-5239

20. Hashimoto H, Mizutani K, Yoshida A (2001) PCT Int Appl. WO 2001047883 A1 20010705

21. Beaulieu PL, Fazal G, Goulet S, Kukolj G, Poirier M, Tsantrizos YS, Jolicoeur E, Gillard J, Poupart MA, Rancourt J (2003) PCT Int Appl. WO 2003010141 A2 20030206

22. Martin SW, Glunz P, Beno BR, Bergstrom C, Romine JL, Scott PE, Newman M, Gao M, Roberts S, Rigat K, Robert F, Dike Q, Galina K, Ying-Kai W (2011) The synthesis and evaluation of a novel class of (E)-3-(1-cyclohexyl-1H-pyrazol-3-yl)-2-methylacrylic acid Hepatitis C virus polymerase NS5B inhibitors. Bioorg Med Chem Lett 21(10):2869-2872

23. Zheng X, Hudyma TW, Martin SW, Bergstrom C, Ding M, He F, Romine J, Poss MA, Kadow JF, Chang C, Wan J, Witmer MR, Morin P, Camac DM, Sheriff S, Beno BR, Rigat KL, Want YK, Fridell R, Lemm J, Qui D, Liu M, Voss S, Pelosi L, Roberts SB, Gao M, Knipe J, Gentles RG (2011) Syntheses and initial evaluation of a series of indolo-fused heterocyclic inhibitors of the polymerase enzyme (NS5B) of the hepatitis C virus. Bioorg Med Chem Lett 21 (10):2925-2929

24. Harder E, Damm W, Maple J, Wu C, Reboul M, Xiang JY, Wang L, Lupyan D, Dahlgren MK, Knight JL et al (2016) OPLS3: a force field providing broad coverage of drug-like small molecules and proteins. J Chem Theory Comput 12(1):281-296

25. Lohmann V, Korner F, Koch J, Herian U, Theilmann L, Bartenschlager R (1999) Replication of subgenomic hepatitis C virus RNAs in a hepatoma cell line. Science 285(5424):110-113 
26. $\mathrm{PDB} 3 \mathrm{Q} 0 \mathrm{Z}$ at 2.29 angstrom resolution with $\mathrm{R}$-work $=0.200$ and $\mathrm{R}$-free $=0.224$

27. Hewawasam P, Tu Y, Gao M, Hanumegowda U, Knipe J, Lemm JA, Parker DD, Rigat KL, Roberts SB, Meanwell NA, Kadow JF (2016) Discovery and preclinical evaluation of potent, orally bioavailable, metabolically stable cyclopropylindolobenzazepine acylsulfonamides as thumb site 1 inhibitors of the hepatitis c virus NS5B RNA-dependent, RNA polymerase. Bioorg Med Chem Lett 26(3):936-940

28. Martin AR, Yang Y (1993) Palladium-catalyzed cross-coupling reactions of organoboronic acids with organic electrophiles. Acta Chem Scand 47:221-230

29. Suzuki A (1999) Recent advances in the cross-coupling reactions of organoboron derivatives with organic electrophiles, 1995-1998. J Organomet Chem 576:147-168

30. Suzuki A (2002) Cross-coupling reactions via organoboranes. J Organomet Chem 653:83-90

31. Beaulieu PL, Gillard J, Bykowski D, Brochu C, Dansereau N, Duceppe J-S, Hache B, Jakalian A, Lagace L, LaPlante S, McKercher G, Moreau E, Perreault S, Stammers T, Thauvette L, Warrington J, Kukolj G (2006) Improved replicon cellular activity of non-nucleoside allosteric inhibitors of HCV NS5B polymerase: From benzimidazole to indole scaffolds. Bioorg Med Chem Lett 16:4987-4993

32. Hudyma TW, Zheng X, He F, Ding M, Bergstrom CP, Hewawasam P, Martin SW, Gentles RG (2006) Preparation of indolecarboxylic acid derivatives as inhibitors of HCV replication. PCT Int Appl. WO 2006020082 A1 2006022

33. Grubbs RH (2003) Handbook of metathesis. Wiley-VCH, Weinheim

34. Furstner A (2000) Angew Chem Int Ed 39:3012

35. Hewawasam P, Tu Y, Hudyma TW, Zhang X, Gentles RG, Kadow JF, Meanwell NA (2014) A practical and efficient synthesis of 6-carboalkoxy-13-cycloalkyl-5H-indolo[2,1-a][2] benzazepine-10-carboxylic acid derivatives. Tetrahedron Lett 55(6):1148-1153

36. Herbst J, Anthony M, Stewart J, Connors D, Chen T, Banks M, Petrillo EW, Agler M (2009) Multiplexing a high-throughput liability assay to leverage efficiencies. Assay Drug Dev Technol 7:294-303

37. Trost BM, Melvin LS Jr (1975) Organic chemistry. Sulfur ylides, emerging synthetic intermediates, vol 31. Academic Press, New York, 346 pp

38. Gentles RG, Ding M, Bender JA, Bergstrom CP, Grant-Young K, Hewawasam P, Hudyma T, Martin S, Nickel A, Regueiro-Ren A et al (2014) Discovery and preclinical characterization of the cyclopropylindolobenzazepine BMS-791325, a potent allosteric inhibitor of the hepatitis C virus NS5B polymerase. J Med Chem 57(5):1855-1879

39. Chen C-N, Shih Y-H, Ding Y-L, Leong MK (2011) Predicting activation of the promiscuous human pregnane $\mathrm{X}$ receptor by pharmacophore ensemble/support vector machine approach. Chem Res Toxicol 24:1765-1778

40. Ekins S, Kortagere S, Iyer M, Reschly EJ, Lill MA, Redinbo MR, Krasowski MD (2009) Challenges predicting ligand-receptor interactions of promiscuous proteins: the nuclear receptor PXR. PLoS Comput Biol 5

41. Wallace BD, Betts L, Talmage G, Pollet RM, Holman NS, Redinbo MR (2013) Structural and functional analysis of the human nuclear xenobiotic receptor PXR in complex with RXR $\alpha$. J Mol Biol 425:2561-2577

42. Wu B, Li S, Dong D (2013) 3D structures and ligand specificities of nuclear xenobiotic receptors CAR, PXR and VDR. Drug Discov Today 18:574-581

43. Kansy M, Senner F, Gubernator K (1998) Physicochemical high throughput screening: parallel artificial membrane permeation assay in the description of passive absorption processes. J Med Chem 41:1007-1010

44. Tran A, Rey E, Pons G, Rousseau M, d'Athis P, Olive G, Mather GG, Bishop FE, Wurden CJ, Labroo R, Trager WF, Kunze KL, Thummel KE, Vincent JC, Gillardin J-M, Lepage F, Levy RH (1997) Influence of stiripentol on cytochrome P450-mediated metabolic pathways in humans: in vitro and in vivo comparison and calculation of in vivo inhibition constants. Clin Pharmacol Ther (St Louis) 62:490-504 
45. Wu C-Y, Benet LZ (2005) Predicting drug disposition via application of BCS: transport/ absorption/elimination interplay and development of a biopharmaceutics drug disposition classification system. Pharm Res 22:11-23

46. Shoghi E, Fuguet E, Bosch E, Rafols C (2013) Solubility-pH profiles of some acidic, basic and amphoteric drugs. Eur J Pharm Sci 48(1-2):291-300

47. Paus R, Ji Y, Vahle L, Sadowski G (2015) Predicting the solubility advantage of amorphous pharmaceuticals: a novel thermodynamic approach. Mol Pharm 12(8):2823-2833

48. Zvyaga T, Chang S-Y, Chen C, Yang Z, Vuppugalla R, Hurley J, Thorndike D, Wagner A, Chimalakonda A, Rodrigues AD (2012) Evaluation of six proton pump inhibitors as inhibitors of various human cytochromes P450: focus on cytochrome P450 2C19. Drug Metab Dispos 40:1698-1711

49. Weaver CD, Harden D, Dworetzky SI, Robertson B, Knox RJ (2004) A thallium-sensitive, fluorescence-based assay for detecting and characterizing potassium channel modulators in mammalian cells. J Biomol Screen 9:671-677

50. Cai X, Walker A, Cheng C, Paiva A, Li Y, Kolb J, Herbst J, Shou W, Weller H (2012) Approach to improve compound recovery in a high-throughput Caco-2 permeability assay supported by liquid chromatography-tandem mass spectrometry. J Pharm Sci 101:2755-2762

51. Jiang H, Demers R, Kandoussi H, Burrell R, Eley T, Kadiyala P, Cojocaru L, Baker C, Ryan J, Aubry AF et al (2015) Sensitive and accurate liquid chromatography-tandem mass spectrometry methods for quantitative determination of a novel hepatitis C NS5B inhibitor BMS-791325 and its active metabolite in human plasma and urine. J Pharm Biomed Anal 107:17-23

52. Obha K, Mizokami M, Lau JYN, Orito E, Ikeo K, Gojobori T (1996) Evolutionary relationship of hepatitis C, pesti-, flavi-, plantviruses, and newly discovered GB hepatitis agents. FEBS Lett 378:232-223

53. Gurney ME, Burgin AB, Magnusson OT, Stewart LJ (2011) Small molecule allosteric modulators of phosphodiesterase 4. Handb Exp Pharmacol 204:167-192

54. PDB ID is 4 NLD

55. Connolly ML (1983) Solvent-accessible surfaces of proteins and nucleic acids. Science 221:709-713

56. Rigat KL, Lu H, Wang Y, Argyrou A, Fanslau C, Beno B, Wang Y, Marcinkeviciene J, Ding M, Gentles RG et al (2014) Mechanism of inhibition for BMS-791325, a novel non-nucleoside inhibitor of hepatitis C virus NS5B polymerase. J Biol Chem 289 (48):33456-33289

57. Sims KD, Lemm J, Eley T, Liu M, Berglind A, Sherman D, Lawitz E, Vutikullird AB, Tebas P, Gao M, Pasquinelli C, Grasela DM (2014) Randomized, placebo-controlled, single-ascendingdose study of BMS-791325, a hepatitis C virus (HCV) NS5B polymerase inhibitor, in HCV genotype 1 infection. Antimicrob Agents Chemother 58:3496-3503

58. Belema M, Nguyen VN, Bachand C, Deon DH, Goodrich JT, James CA, Lavoie R, Lopez OD, Martel A, Romine JL et al (2014) Hepatitis C virus NS5A replication complex inhibitors: the discovery of daclatasvir. J Med Chem 57(5):2013-2032

59. Belema M, Meanwell NA (2014) Discovery of daclatasvir, a pan-genotypic hepatitis C virus NS5A replication complex inhibitor with potent clinical effect. J Med Chem 57(12):5057-5071

60. Scola PM, Sun L, Wang AX, Chen J, Sin N, Venables BL, Sit S, Chen Y, Cocuzza A, Bilder DM et al (2014) The discovery of asunaprevir (BMS-650032), an orally efficacious NS3 protease inhibitor for the treatment of hepatitis C virus infection. J Med Chem 57(5):1730-1752

61. Kao J-H, Yu M-L, Peng C-Y, Heo J, Chu C-J, Chang T-T, Lee Y-J, Hu T-H, Yoon KT, Paik SW, Lim Y, Lim S, Ahn SH, Isakov V, McPhee F, Hu W, Swenson ES, Yin PD, Treitel M (2017) Daclatasvir/asunaprevir/beclabuvir, all-oral, fixed-dose combination for patients with chronic hepatitis C virus genotype 1. J Gastroenterol Hepatol 32(12):1998-2005

62. Muir AJ, Poordad F, Lalezari J, Everson G, Dore GJ, Herring R, Sheikh A, Kwo P, Hézode C, Pockros PJ, Tran A, Yozviak J, Reau N, Ramji A, Stuart K, Thompson AJ, Vierling J, Freilich B, Cooper J, Ghesquiere W, Yang R, McPhee F, Hughes EA, Swenson ES, Yin PD 
(2015) Daclatasvir in combination with asunaprevir and beclabuvir for hepatitis $\mathrm{C}$ virus genotype 1 infection with compensated cirrhosis. J Am Med Assoc 313(17):1736-1744

63. Toyota J, Karino Y, Suzuki F, Ikeda F, Ido A, Tanaka K, Takaguchi K, Naganuma A, Tomita E, Chayama K, Fujiyama S, Inada Y, Yoshiji H, Watanabe H, Ishikawa H, Hu W, McPhee F, Linaberry M, Yin PD, Swenson ES, Kumada H (2017) Daclatasvir/asunaprevir/beclabuvir fixed-dose combination in Japanese patients with HCV genotype 1 infection. J Gastroenterol 52(3):385-395

64. AbuTarif M, He B, Ding Y, Sims K, Zhu K, Rege B, Pursley J, Wind-Rotolo M, Li W, Bertz RJ (2014) The effect of steady-state BMS-791325, a non-nucleoside HCV NS5B polymerase inhibitor, on the pharmacokinetics of midazolam in healthy Japanese and Caucasian males. 15th international workshop on clinical pharmacology of HIV and hepatitis therapy. Washington DC, May 19-21

65. Tatum H, Thuluvath PJ, Lawitz E, Martorell C, DeMicco M, Cohen S, Rustgi V, Ravendhran N, Ghalib R, Hanson J, Zamparo J, Zhao J, Cooney E, Treitel M, Hughes E (2015) A randomized, placebo-controlled study of the NS5B inhibitor beclabuvir with peginterferon/ribavirin for $\mathrm{HCV}$ genotype 1. J Viral Hepatol 22(8):658-664

66. Everson GT, Sims KD, Rodriguez-Torres M, Hézode C, Lawitz E, Bourlière M, LoustaudRatti V, Rustgi V, Schwartz H, Tatum H, Marcellin P, Pol S, Thuluvath PJ, Eley T, Wang X, Huang SP, McPhee F, Wind-Rotolo M, Chung E, Pasquinelli C, Grasela DM, Gardiner DF (2014) Efficacy of an interferon- and ribavirin-free regimen of daclatasvir, asunaprevir, and BMS-791325 in treatment-naive patients with HCV genotype 1 infection. Gastroenterology 146 (2):420-429

67. Hassanein T, Sims KD, Bennett M, Gitlin N, Lawitz E, Nguyen T, Webster L, Younossi Z, Schwartz H, Thuluvath PA, Zhou H, Raga B, McPhee F, Zhou N, Wind-Retools M, Chung E, Griffies A, Grasela DM, Gardiner DF (2015) A randomized trial of daclatasvir in combination with asunaprevir and beclabuvir in patients with chronic hepatitis $C$ virus genotype 4 infection. J Hepatol 62(5):1204-1206 